\title{
Analisis Risiko Pengadaan Tanah Untuk Eksplorasi dan Eksploitasi Minyak dan Gas Bumi (Studi Kasus : PT.Pertamina EP- Paku Gajah Development Project)
}

\author{
Oleh: \\ Presetyo Firgianto \\ Prof. Dr. S. Pantja Djati, M.Si., MA
}

\section{ABSTRAK}

Upstream oil and gas activities both searching up to oil and gas production are government programs where activities are regulated in legislation. Before drilling, to obtain oil and gas reserves, the need for land for drilling activities is a step that must be passed. Since the upstream oil and gas activities are government programs, the government guarantees the availability of land for such activities that can be classified into the public interest and set forth in Law No. 2 of 2012 on Land Procurement for Development for the Public Interest.

The formulation of the problem in this research is : How the stages of activities Land acquisition for the public interest PT.Pertamina EP - Paku Gajah Development Project?, What are the opportunities and impacts at each stage of the activity? Land acquisition for public interest PT.Pertamina EP - Paku Gajah Development Project?, and How is the mitigation effect of each stage of Land Acquisition activities for

This research uses semi-quantitative descriptive method. The data collection tool used is questionnaire with liekert scale (I-5).

The results of this study indicate that the stages of land acquisition for the public interest consists of planning, preparation, implementation, and delivery of results.

Exposure to the results of the research analysis shows that in the stages of land acquisition for the public interest PT.Pertamina EP-Paku Gajah Development Project has the potential to face risks, namely:

a. The results of identification of operational risks related to the planning stages of particular concern are:

- Related Filing Documents, High risk,

b. The results of the identification of operational risks and related to the stages of Preparation of particular concern are:

- Related to Notification of Development Plan, Medium risk,

- Initial Data Collection, High risk,

- Related to Public Consultation, High risk,

- Related to Public Consultation, High risk,

- Related to Location Determination, Medium risk,

c. Social risk identification outcomes and related to Preparation stages of particular concern are:

- Related to Notification of Development Plan, Medium risk,

- Initial Data Collection, High risk, 
- Related to Public Consultation, High risk,

- Related to Public Consultation, High risk,

- Related to Location Determination, Medium risk,

d. The results of identification of operational risks and related to the Implementation stage of special attention are:

- Related Inventory and Identification, Low risk,

- Related to Indemnification, Substantial risk,

- Related to the Indemnification of Indemnification, substantial risk,

- Related to Indemnification, Substantial risk,

- Related to Removal and Abolition of Land Rights, substantial rights,

e. The results of identification of Social risks and related to the Implementation stage of special attention are:

- Related Inventory and Identification, Low risk,

- Related to Indemnification, Substantial Risk,

- Related to Deliberation Determination of compensation, Substantial risk,

- Related to Indemnification, Substantial risk,

- Related to Removal and Abolition of Land Rights, Substantial risk,

f. The results of the identification of operational risks and related to the Delivery stage of the results of particular concern are:

- Related to Results Delivery, Medium risk,

These risks should be managed through risk management that includes identifying, measuring and mitigating (minimizing opportunities and impacts for the Stages of Land Acquisition for the Public Interest of PT.Pertamina EP - Paku Gajah Development Project. Each stage of Land Acquisition for the Public Interest of PT.Pertamina EP - Paku Gajah Development Project which has high risk value, mitigation is to stop the way or implementation of the activity, and change the way or application of the activity in new way or application, in order to the risk of such activities can be minimized. And the stages that have Substantial, Medium, and Low risk value, mitigas conducted are follow up on the way or application of the activity.

Keywords: upstream oil and gas, land acquisition, public interest, mitigation

\section{PENDAHULUAN}

\section{I.I Latar Belakang}

Kegiatan hulu minyak dan gas bumi dalam hal pencarian hingga produksi minyak dan gas bumi merupakan program pemerintah dimana kegiatan tersebut dilimpahkan kepada Satuan Kerja Khusus Pelaksana Kegiatan Usaha hulu Minyak dan gas Bumi (SKK Migas) dan Kontraktor Kerja Sama (KKKS) yang memiliki kontrak kerja kepada SKK Migas.

Untuk mendukung program pemerintah yaitu percepatan peningkatan produksi minyak dan gas bumi yang tertuang dalam Instruksi Presiden RI Nomor 2 tahun 2012 tentang Peningkatan Produksi Minyak Bumi Nasional yaitu Pencapaian produksi minyak bumi nasional paling sedikit rata-rata I,0I juta barel per hari pada tahun 2014 (Republik Indonesia) untuk mendukung peningkatan ketahanan energi. PT. Pertamina EP adalah salah satu KKKS yang terdaftar dan memiliki kontak kerjasama dengan SKK Migas yang merupakan anak perusahaan dari PT.Pertamina (Persero) bergerak dalam sektor hulu minyak dan gas bumi menerapkan salah satu strategi peningkatan produksi dengan membentuk beberapa project.

Paku Gajah Development Project adalah sebuah kelompok kerja yang dimiliki oleh PT.Pertamina EP yang di bentuk untuk mendukung instruksi Presiden RI Nomor 2 tahun 2012 yang bertugas untuk mencari dan menghasilkan minyak dan gas bumi untuk menambah produksi PT.Pertamina EP. Paku Gajah Development Project berada di wilayah Kerja (WK) PT.Pertamina EP Asset 2 Sumatra Selatan, sehingga apabila project tersebut selesai maka baik hasil maupun asetnya akan di serahkan kepada Asset 2. Keberhasilan Paku Gajah Developmet Project dalam menemukan minyak dan gas bumi berpengaruh terhadap devisa bagi PT.Pertamina EP, PT.Pertamina (Persero), dan Negara.

Sebelum melakukan pengeboran untuk mendapatkan cadangan Minyak dan Gas Bumi, kebutuhan lahan untuk kegiatan pengeboran merupakan suatu tahapan yang harus dilewati. Dikarenakan kegiatan hulu minyak dan gas bumi adalah program Pemerintah, maka Pemerintah menjamin akan ketersediaannya lahan untuk kegiatan hulu minyak dan gas bumi. Kebutuhan lahan 
tersebut dapat dimasukan kedalam pengadaan lahan untuk kepentingan umum yang diatur dalam UndangUndang No.2 Tahun 2012 Tentang Pengadaan Tanah Untuk Pembangunan Bagi Kepentingan Umum dan Peraturan Presiden Republik Indonesia Nomor 7 I Tahun 2012 Tentang Penyelenggaraan Pengadaan Tanah Bagi Pembangunan Untuk Kepentingan Umum. Namun sering kali pengadaan tanah untuk kepentingan umum terhambat atau tidak sesuainya kegiatan pengadaan tanah untuk kepentingan umum dengan tata waktu yang sudah ditentukan, imbasnya adalah tahapan selanjutnya atau tahapan pengeboran menjadi terhambat.

\section{I.2 Permasalahan}

Berdasarkan latar belakang di atas, maka identifikasi masalah dalam penelitian ini adalah sebagai berikut:

I Pemilik tanah menolak pembebasan tanahnya untuk kegiatan eksplorasi dan eksploitasi Migas. Sehingga hal ini menjadi pemghambat pengadaan tanah untuk kegiatan eksplorasi tersebut.

2 Pemilik tanah sering kali tidak menghadiri kegiatan atau tahapan dari pengadaan lahan untuk kepentingan umum yang mewajibkan pemilik tanah untuk hadir, sehingga kegiatan pengadaan tanah untuk kepentingan umum menjadi terhambat. Ketidaksesuaian data awal dengan data dilapangan sehingga ketidaksesuaian ini sangat berbeda dan mengakibatkan revisi pengajuan ulang. $\mathrm{Hal}$ ini menjadi penghambat dalam pengadaan tanah untuk kegiatan eksplorasi dan eksploitasi Migas.

\section{I.3 Perumusan Masalah}

Pengadaan Tanah untuk kepentingan umum mempunyai peranan penting dalam hal pembangunan

I. agaimana tahapan kegiatan Pengadaan tanah untuk kegiatan eksplorasi dan eksploitasi Migas PT. Pertamina EP - Paku Gajah Development Project?

2. Berapa besar peluang dan dampak pada setiap tahapan kegiatan Pengadaan tanah untuk kegiatan eksplorasi dan eksploitasi Migas PT.Pertamina EP - Paku Gajah Development Project?

3. Bagaimana upaya pengendalian (mitigasi) dari setiap tahapan kegiatan Pengadaan tanah untuk kegiatan eksplorasi dan eksploitasi Migas PT. Pertamina EP - Paku Gajah Development Project ?

\section{I.4 Tujuan}

Penelitian ini dimaksudkan untuk:

I. Mengidentifikasi tahapan kegiatan pengadaan tanah untuk kegiatan eksplorasi dan eksploitasi Migas

2. Mengukur besarnya peluang dan dampak (risiko) dari setiap tahapan kegiatan pengadaan tanah untuk kegiatan eksplorasi dan eksploitasi Migas

3. Menetapkan kebijakan pengendalian guna meminimalkan risiko (mitigasi) pada setiap tahapan kegiatan pengadaan tanah untuk kegiatan eksplorasi dan eksploitasi Migas

\section{I.5 Ruang Lingkup}

I. Dalam penelitian ini obyek penelitian adalah PT.Pertamina EP - Paku Gajah Development Project di wilayah administrasi Kabupaten Ogan Komering Ulu dan Muara Enim provinsi Sumatera Selatan.

2. Dalam Undang-Undang No.2Tahun 20 I 2 Tentang Pengadaan Tanah Untuk Pembangunan Bagi Kepentingan Umum, kepentingan umum adalah kepentingan bangsa, negara, dan masyarakat yang harus diwujudkan oleh pemerintah dan digunakan sebesar-besarnya untuk kemakmuran rakyat. Dalam tesis ini kegiatan eksplorasi dan eksploitasi migas termasuk dalam kepentingan umum.

\section{LANDASAN TEORI}

\section{I Pengadaan Tanah}

Pengadaan tanah adalah setiap kegiatan untuk mendapatkan tanah dengan cara memberikan ganti kerugian kepada yang berhak atas tanah tersebut. (Republik Indonesia)

Pengadaan tanah punya kaitan langsung dengan penggunaan atau pemanfaatan tanah sesuai dengan Peraturan Pemerintah Nomor 16 Tahun 2004 Tentang 
Penatagunaan Tanah. Prosedur hukum pengadaan tanah harus disertai dengan pelepasan/penyerahan hak dari pemegang hak atas tanah kepada pihak lain. Pelepasan hak itu sendiri bisa berupa jual beli, penyerahan, hibah atau pencabutan. (Syah, 20I5)

\subsection{Eksplorasi dan Eksploitasi}

\subsection{Eksplorasi}

Eksplorasi adalah kegiatan yang bertujuan memperoleh informasi mengenai kondisi geologi untuk menemukan dan memperoleh perkiraan cadangan Minyak dan Gas Bumi di Wilayah Kerja yang ditentukan (Republik Indonesia). dapat disimpulkan bahwa Eksplorasi adalah suatu kegiatan lanjutan dari prospeksi yang meliputi pekerjaanpekerjaan untuk mengetahui ukuran, bentuk, posisi, kadar rata-rata dan besarnya cadangan serta "studi kelayakan" dari minyak dan gas bumi yang telah ditemukan.

\subsubsection{Eksploitasi}

Rangkaian kegiatan yang bertujuan untuk menghasilkan Minyak dan Gas Bumi dari Wilayah Kerja yang ditentukan, yang terdiri atas pengeboran dan penyelesaian sumur, pembangunan sarana pengangkutan, penyimpanan, dan pengolahan untuk pemisahan dan pemurnian Minyak dan Gas Bumi di lapangan serta kegiatan lain yang mendukungnya (Republik Indonesia).

Eksploitasi dapat diartikan sebagai tindakan berkelanjutan setelah dilakukan eksplorasi dan hasil dari eksplorasi itu menunjukan adanya sumber minyak dan gas bumi.

\subsection{Risiko}

Risiko adalah kemungkinan atau peluang terjadinya sesuatu yang dapat meimbulkan suatu dampak dari suatu sasaran. Risiko tersebut diukur berdasarkan adanya kemungkinan terjadinya suatu kasus atau konsekuensi yang dapat ditimbulkannya (Australian Standard/New Zealand Standard 4360:2004, 2004)

\subsection{Manajemen Risiko}

Manajemen risiko adalah budaya, proses dan struktur yang mengacu langsung pada pengetahuan efektif terhadap kesempatan potensial dan efek yang merugikan. (Australian Standard/New Zealand Standard 4360:2004, 2004). Manajemen risiko merupakan suatu kumpulan dari berbagai tahapan kegiatan yang bertujuan untuk mengelola risiko-risiko keselamatan dan kesehatan kerja dalam suatu aktifitas kegiatan. (Australian Standard/New Zealand Standard 4360:2004, 2004)

\subsection{Manfaat Manajemen Risiko}

Terdapat beberapa manfaat manajemen risiko yaitu: (Australian Standard/New Zealand Standard 4360:2004, 2004)

I. Memperkecil kemungkinan suatu kejadian yang ridak diinginkan dan mengurangi efek yang ditimbulkan dari kemungkinan tersebut.

2. Membantu meningkatkan perencanaan kerja yang efektif.

3. Menciptakan lingkungan kerja yang aman dan pencapaian performa perusahaan menjadi lebih baik

4. Meningkatkan produktifitas kerja.

5. Mendapat keuntungan dari segi ekonomi dan kemudahan untuk memenuhi target perusahaan dan perlindungan aset.

6. Meningkatkan reputasi/citra organisasi dan perusahaan.

7. Meningkatkan kesehatan dan keselamatan serta kesejahteraan karyawan.

\subsection{Proses Manajemen Risiko}

Terdapat beberapa tahapan dalam melaksanakan manajemen risiko menurut yaitu : (Australian Standard/New Zealand Standard 4360:1999, 1999)

I. Menetapkan tujuan dan lingkup pelaksanaan maajemen risiko

2. Melaksanakan identifikasi bahaya .

3. Melakukan analisis risiko untuk menetapkan kemungkinan dan konsekuensi yang akan terjadi serta menetapkan tingkat risiko.

4. Menetapkan evaluasi untuk menetapkan skala prioritas dan membandingkan dengan kriteria yang ada.

5. Melakukan pengendalian risiko yang tidak dapat diterima 
6. Melakukan pemantauan dan tinjauan ulang program manajemen risiko yang telah dilaksanakan.

7. Komunikasi dan konsultasi yang dilakukan dalam proses manajemen risiko yang melibatkan pihak internal dan eksternal.

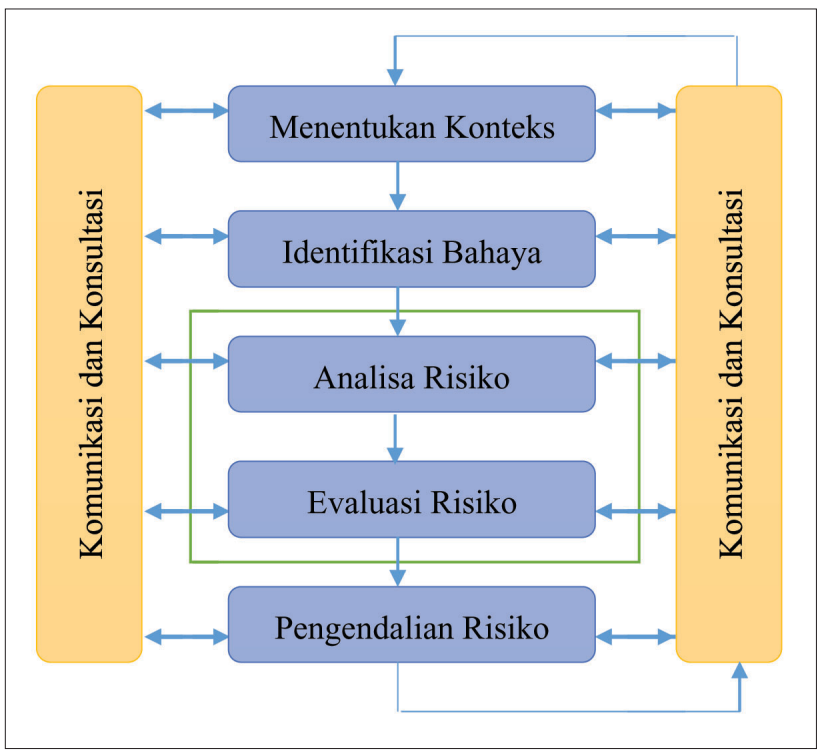

Gambar 2.I Proses Manajemen Risiko

(Australian Standard/New Zealand Standard 4360:2004, 2004)

\subsection{Penetapan Konteks}

Penetapan konteks eksternal, konteks internal, dan konteks manajemen risiko dimana proses manajemen risiko akan diterapkan. Kriteria yang digunakan pada saat risiko akan dievaluasi harus disusun dan struktur analisis didefinisikan.

\subsubsection{Identifikasi Risiko}

Identifikasi bahaya adalah langkah dalam proses manajemen risiko untuk mengidentifikasi semua kemungkinan bahaya atau risiko yang mungkin terjadi di lingkungan kegiatan dan bagaimana dampak atau keparahannya jika terjadi. (Ramli, 20I0)

\subsubsection{Analisis Risiko}

Analisis risiko adalah suatu kegiatan sistemik dengan menggunakna informasi yang ada untuk mendererminasi seberapa besar konsekuensi dan tingkat keseringan suatu kejadian yang ditimbulkan. Analisis ini harus dapat terjadi. Tujuan dilakukannya analisis risiko adalah untuk membedakan antara risiko kecil dengan risiko besar dan menyediakan data untuk membantu evaluasi dan penanganan risiko (Australian Standard/ New Zealand Standard 4360:1999, 1999)

\subsubsection{Evaluasi Risiko}

Evaluasi risiko merupakan suatu proses membandingkan estimasi level risiko dengan kriteria yang telah ditentukan dahulu dan mempertimbangkan keseimbangan antara manfaat potensial dan hasil yang tidak menguntungkan untuk menilai dan menentukan prioritas pengendalian risiko berdasarkan kriteria yang ditetapkan mengenai batasan risiko mana yang bisa diterima, risiko mana yang harus dikurangi atau dikendalikan dengan cara yang lain. (Australian Standard/ New Zealand Standard 4360:2004, 2004)

\subsubsection{Pengendalian Risiko}

Pengendalian risiko yaitu suatu upaya penanganan dan pengendalian terhadap risiko, terutama risiko dengan tingkat tinggi serta mempertimbangkan aspek efektifitas dan efisiensi. pengendalian risiko dapat dilakukan dengan berbagai macam metode (Republik Indonesia), yaitu :

a. Pengendalian teknis atau rekayasa yang meliputi eliminasi, subtitusi, isolasi, ventilasi (engineering control)

b. Pendidikan dan pelatihan

c. Pembangunan kesadaran dan motivasi yang meliputi sistem bonus, insentif, penghargaan dan motivasi diri.

d. Evaluasi melalui internal audit, penyelidikan dan etiologi.

e. Penegakan hukum.

Dalam melakukan langkah-langkah untuk mengatasi bahaya yang timbul, dibutuhkan suatu skala prioritas yang dapat membantu dalam pemilihan pengendalian suatu bahaya yang disebut dengan hirarki pengendalian. Urutan prioritas atau hirarki tersebut (Suardi, 2005), yaitu:

a. Eliminasi adalah langkah ideal yang dapat dilakukan dan harus menjadi pilihan pertama dalam melakukan pengendalian risiko. Eliminasi berarti menghilangkan peralatan yang dapat menimbulkan bahaya. 
b. Substitusi, prinsip dari sistem pengendalian ini adalah mengganti sumber risiko dengan saran atau peralatan lain yang tingkat risikonya lebih rendah atau tidak ada.

c. Engineering control dilakukan dengan mengubah desain tempat kerja, peralatan, atau proses kerja untuk mengurangi tingkat risiko. Ciri khusus dari tahap ini adalah melibatkan pemikiran yang lebih mendalam bagaimana membuat lokasi kerja yang lebih aman dengan melakukan pengaturan ulang lokasi kerja, memodifikasi peralatan, melakukan kombinasi kegiatan, perubahan prosedur, dan mengurangi frekuensi dalam melakukan kegiatan berbahaya.

d. Administrative control, dalam tahap ini pengendalian dilakukan dengan menggunakan prosedur, standar operasi kerja, atau panduan sebagai langkah untuk mengurangi risiko. Pengendalian administrasi dapat diartikan juga sebagai pengendalian bahaya dengna melakukan modifikasi pada interaksi pekerja dengna lingkungan kerja seperti, rotasi kerja, shift kerja, serta pengembangan standar kerja. Akan tetapi banyak kasus yang ada, pengendalian administrasi tetap membutuhkan sarana pengendalian risiko lainnya.

e. Alat pelindung diri (APD) adalah pilihan terakhir yang dapat dilakukan untuk mencegah papatan bahaya pada pekerja. Penggunaan APD ini disarankan hanya digunakan bersamaaan dengan penggunaan alat pengendali lainnya. Dengan demikian perlindungan keamanan dan kesehatan personel akan lebih efektif.

\subsection{Pemantauan dan Tinjauan Ulang}

Pemantauan bertujuan untuk melakukan survei rutin terhadap hasil yang dicapai, kemudian dibandingkan dengan hasil yang diharapkan atau target yang telah dibuat. Sedangkan tinjauan ulang bertujuan melakukan investigasi secara berkala terhadap situasi terkini. Pemantauan dan tinjauan ulang perlu dilakukan untuk memonitor efektifitas seluruh tahapan proses manajemen risiko. Hal ini penting untuk perbaikan berkelanjutan. Risiko dan efektifitas pengendalian risiko perlu dimonitor untuk meyakinkan bahwa perubahan situasi tidak mengubah prioritas risiko. (Australian Standard/New Zealand Standard 4360:2004, 2004)

\subsection{Komunikasi dan Konsultasi}

Komunikasi dan konsultasi yang baik dapat menjamin pihak yang terlibat dan bertanggung jawab terhadap perencanaan dan pelaksanaan manajemen risiko dan pihak lain yang berkepentingan memiliki pemahaman yang sama mengenai pengambilan suatu keputusan dan tindakan-tindakan yang perlu dilakukan.

\subsection{Peraturan undang-undang yang dipergunakan}

Proses Pengadaan Tanah Untuk Kepentingan Umum diatur dalam undangundang Republik Indonesia, yaitu Undang-Undang Nomor 2 Tahun 2012 Tentang "Pengadaan Tanah Untuk Pembangunan Bagi Kepentingan Umum" (Republik Indonesia) dan Peraturan Presiden Nomor 7I Tahun 2012 tentang "Penyelenggaraan Pengadaan Tanah Bagi Pembangunan Untuk Kepentingan Umum (Republik Indonesia). Peraturan Presiden No.7I Tahun 2012 mengalami empat perubahan yaitu : Peraturan Presiden Nomor 40 Tahun 2014 tentang "Perubahan atas peraturan Presiden Nomor 7I tahun 2012 Tentang Penyelenggaraan Pengadaan Tanah Bagi Pembangunan Untuk Kepentingan Umum" (Republik Indonesia) . kemudian muncul Peraturan Presiden Nomor 99 Tahun 2014 tentang "Perubahan Kedua Atas Peraturan Presiden Nomor 7I Tahun 2012 Tentang Penyelenggaraan Pengadaan Tanah Bagi Pembangunan Untuk Kepentingan Umum" (Republik Indonesia). Kemudian peraturan tersebut kembali direvisi dengan munculnya Peraturan Presiden Nomor 30 tahun 2015 Tentang "Perubahan Ketiga Atas Peraturan Presiden Nomor 7I Tahun 2012 Tentang Penyelenggaraan Pengadaan Tanah Bagi Pembangunan Untuk Kepentingan Umum" (Republik Indonesia). Dan terakhir untuk saat ini peraturan tersebut kembali di revisi menjadi Peraturan Presiden Nomor I48 tahun 2015 Tentang "Perubahan Keempat Atas Peraturan Presiden Nomor 7I Tahun 20 I2Tentang Penyelenggaran Pengadaan Tanah Bagi Pembangunan Untuk Kepentingan Umum" (Republik Indonesia).

Undang-Undang Dasar Tahun 1945 Pasal 33 ayat (3) menjelaskan bahwa Bumi, air dan kekayaan alam yang terkandung didalamnya dikuasai oleh Negara dan dipergunakan untuk sebesar-besarnya kemakmuran rakyat. (Republik Indonesia) 
Peningkatan produksi minyak dan gas bumi diatur dalam Instruksi Presiden No.2 Tahun 2012 Tentang Peningkatan produksi minyak dan gas bumi Nasional yang berisikan Dalam rangka pencapaian produksi minyak bumi nasional paling sedikit rata- rata I,0I juta barrel per hari pada Tahun 2014 untuk mendukung peningkatan ketahanan energi (Republik Indonesia).

\subsection{Kerangka Pemikiran}

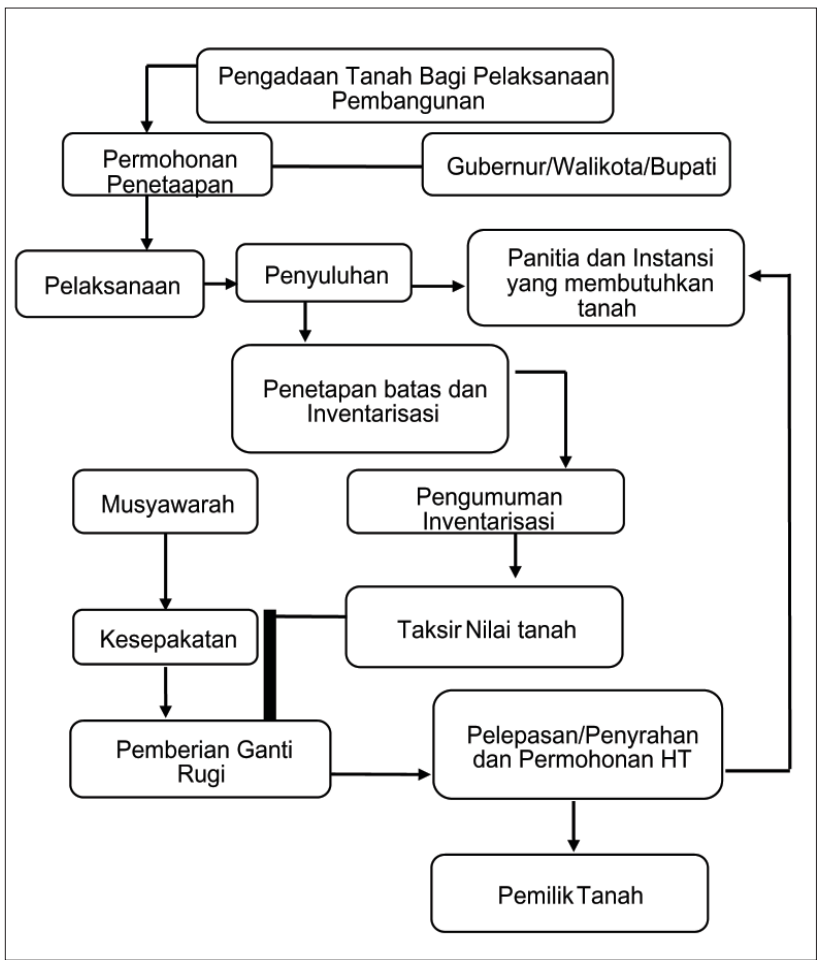

\section{METODE PENELITIAN}

\section{I Desain Penelitian}

Penelitian ini merupakan jenis penelitian deskriptif semi-kuantitatif, dimana dilakukan penelitian terhadap risiko yang terjadi pada setiap tahapan pengadaan tanah untuk kepentingan umum dengan mengkombinasikan inspeksi di lapangan dengan teknik penilaian risiko, penilaian risiko dilakukan berdasarkan tahapan manajemen risiko dengan cara pengukuran peluang dan dampak dari setiap tahapan pengadaan tanah untuk kepentingan umum menggunakan alat berupa kuesioner ditujukan kepada karyawan PT.Pertamina EP-Paku Gajah Development Project.

\subsection{Waktu Pelaksanaan Penelitian}

Penelitian di laksanakan pada semester genap 20I6/20I7 yaitu antara bulan Maret 2017 sampai dengan Bulan Agustus 2017.

\subsection{Definisi Operasional Variabel}

Tabel 3.I Operasional Variabel

\begin{tabular}{|c|c|c|c|}
\hline Variabel & Indikator & Ukuran & Skala \\
\hline \multirow{4}{*}{$\begin{array}{l}\text { Pengadaan } \\
\text { Tanah } \\
\text { Untuk } \\
\text { Kepentingan } \\
\text { Umum }\end{array}$} & $\begin{array}{l}\text { Peluang, didapatkan } \\
\text { dengan cara metode } \\
\text { kuesioner }\end{array}$ & $\begin{array}{l}\text { Tinggi rendahnya } \\
\text { Peluang kejadian } \\
\text { kejadian yang tidak } \\
\text { dikehendaki }\end{array}$ & $\begin{array}{l}\text { Skala } \\
\text { Likert }\end{array}$ \\
\hline & $\begin{array}{l}\text { Dampak, didapatkan } \\
\text { dengan cara metode } \\
\text { kuesioner }\end{array}$ & $\begin{array}{l}\text { Tinggi rendahnya } \\
\text { dampak kejadian } \\
\text { kejadian yang tidak } \\
\text { dikehendaki }\end{array}$ & $\begin{array}{l}\text { Skala } \\
\text { Likert }\end{array}$ \\
\hline & $\begin{array}{l}\text { Diagram Peluang } \\
\text { dampak, didapatkan } \\
\text { dengan menggunakan } \\
\text { cara peluang dikalikan } \\
\text { dampak } \\
\end{array}$ & $\begin{array}{l}\text { Tinggi rendahnya } \\
\text { Diagram peluang } \\
\text { dampak }\end{array}$ & $\begin{array}{l}\text { Skala } \\
\text { Likert }\end{array}$ \\
\hline & $\begin{array}{l}\text { Distribusi Risiko, } \\
\text { didapat nilai dari dampak } \\
\text { setiap kejadian yang di } \\
\text { dapat dengan cara } \\
\text { kuesioner }\end{array}$ & $\begin{array}{l}\text { Tinggi rendahnya } \\
\text { tingkat distribusi } \\
\text { risiko }\end{array}$ & $\begin{array}{l}\text { Skala } \\
\text { Likert }\end{array}$ \\
\hline
\end{tabular}

Sumber : Diolah pada, 2017

\subsection{Data}

\subsection{Proses Bisnis}

Peneliti mendapatkan data proses bisnis dari pengadaan lahan untuk kepentingan umum berdasarkan kegiatan pengadaan lahan untuk kegiatan eksplorasi dan ekploitasi yang dilakukan oleh PT.Pertamina EP - Paku Gajah Development Project dengan wilayah kerja di wilayah administrasi Kab.Muara Enim dan Ogan Komering Ulu yang dilakukan dari tahun 20I4-20I7. Tahapan pengadaan lahan untuk kepentingan umum tersebut dijelaskan dalam Undang-Undang Nomor 2 Tahun 2012 Tentang "Pengadaan Tanah Untuk Pembangunan Bagi Kepentingan Umum" (Republik Indonesia) dan Peraturan Presiden Nomor 7I Tahun 2012 tentang 
"Penyelenggaraan Pengadaan Tanah Bagi Pembangunan Untuk Kepentingan Umum (Republik Indonesia).

\subsection{Analisis Data}

\subsection{Diagram Peluang Dampak}

Diagram peluang dampak menampilkan kejadian yang tidak dikehendaki dalam sebuah diagram. Tahapan untuk menampilkan sebuah kejadian yang tidak diinginkan, misalnya kejadian A, dalam diagram peluang-dampak adalah sebagai berikut (Fraser \& J. Simkins, 2010):
a. Perkirakan peluang $A, p(A)$
b. Perkirakan dampak dari $A, D(A)$
c. Perkirakan risiko dengan mengalikan peluang dan dampak dari $A, L=p(A) \times D(A)$

d. Letakkan $A$ dalam diagram peluang-dampak

\section{ANALISIS DAN INTERPRETASI}

\section{I Data}

\section{I.I Proses Bisnis}

Berdasarkan Undang-Undang Nomor 2 Tahun 20I2Tentang "Pengadaan Tanah Untuk Pembangunan Bagi Kepentingan Umum” (Republik Indonesia) dan Peraturan Presiden Nomor 7I Tahun 2012 tentang "Penyelenggaraan Pengadaan Tanah Bagi Pembangunan Untuk Kepentingan Umum” (Republik Indonesia) memberikan seperti bagan di bawah ini: ketetapan tentang tahapan-tahapan yang harus dilalui dalam proses pengadaan tanah untuk kepentingan umum. Adapun tahapan yang harus dilalui diklasifikasikan menjadi 4 (empat) tahapan yaitu : Perencanaan, Persiapan, Pelaksanaan, dan Penyerahan Hasil seperti pada bagan dibawah ini :

\section{Perencanaan}

Merupakan tahapan pengajuan dokumen pengadaan tanah kepada Gubernur setempat yang memuat dasar, materi, dan studi kelayakan dari pengadaan tanah.

Adapun dokumen tersebut harus mencakup sebagai berikut :

I. Rencana tata ruang wilayah, Prioritas pembangunan.

2. Rencana pembangunan jangka menengah, Rencana strategis.

3. Rencana kerja pemerintah instansi yang bersangkutan.
4. Maksud dan tujuan rencana pembangunan

5. Data awal penguasaan dan pemilikan atas tanah.

6. Letak tanah, status tanah dan luas tanah yang dibutuhkan, termasuk jangka waktu pengadaan tanah.

7. Perkiraan waktu yang diperlukan untuk masingmasing tahapan pelaksanaan pengadaan tanah, termasuk untuk pembangunannya.

8. Survei sosial ekonomi dan Kelayakan lokasi, yang akan terkena dampak.

9. Study budaya masyarakat, politik, keamanan, agama dan amdal.

10. Analisis mengenai kesesuaian fisik lokasi dituangkan dalam peta (rencana lokasi pembangunan.)

II. Perkiraan nilai ganti kerugian tanah, ruang atas tanah dan bawah tanah, bangunan, tanaman, dan benda yang berkaitan dengan tanah serta rencana penganggaran.

12. Besarnya anggaran, sumber anggaran, dan rincian alokasi anggaran untuk perencanaan, persiapan, pelaksanaan, penyerahan hasil, administrasi dan pengelolaan, serta sosialisasi.

13. Analisis biaya yang diperlukan dan manfaat pembangunan bagi wilayah dan masyarakat.

\section{Persiapan}

Atas Dasar Dokumen Perencanaan, Gubernur membentuk Tim Persiapan, Tim Kajian Dan Sekretariat Provinsi dengan durasi waktu maksimal 10 Hari Kerja semenjak berkas diterima oleh Gubernur.

Pada tahapan Persiapan ini, Gubernur memiliki wewenang apakah proses pengadaan tanah tersebut dilimpahkan kepada Bupati/Walikota atau dilakukan oleh

Gubernur itu sendiri. Tahapan dari tahapan persiapan antara lain sebagai berikut :

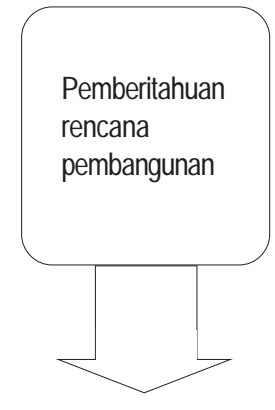

Maksud dan tujuan rencana pembangunan.

- Letaktanah dan luas tanah yang dibutuhkan.

- Tahapan rencana pengadaan tanah.

- Perkiraan jangka waktu pelaksanaan pengadaan tanah.

- Perkiraan jangka waktu pelaksanaan pembangunan.

- Informasi lainnya yang dianggap perlu.

- Pemberitahuan disampaikan secara langsung kepada masyarakat melalui sosialisasi, tatap muka dan surat pemberitahuan 


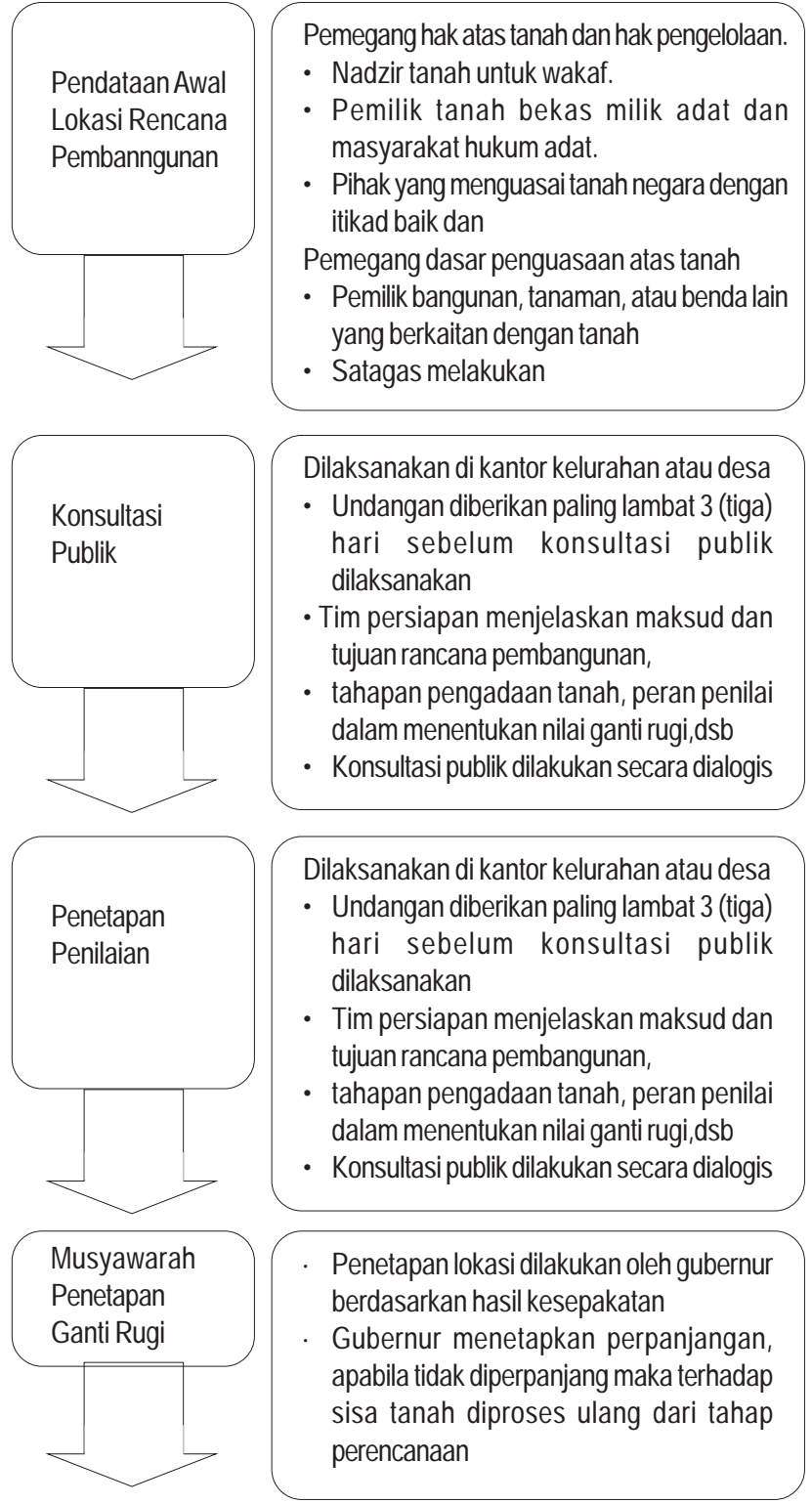

Penetapan Lokasi ini Berlaku 2 Tahun sejak ditetapkan dan dapat diperpanjang I Tahun. Adapun durasi kegiatan ini memakan waktu maksimal 207 hari

\section{Pelaksanaan}

Setelah ditetapkannya suatu lokasi oleh Gubernur atau Bupati/Walikota jika dilimpahkan, maka tahapan selanjutnya adalah tahapan pelaksanaan. Yaitu pembentukan tim pelaksana, Penyusunan Rencana Kerja dan rapat Koordinasi, Pembentukan satuan tugas, serta penyusunan persiapan kerja.

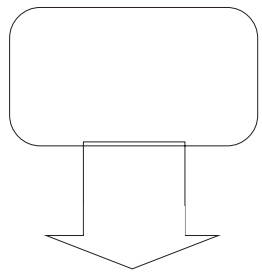

- Pengajuan pengadaan tanah kepada ketua pelaksana

- Pelaksana pengadaan tanah membuat rencana kerja, agenda rapat, dan merumuskan strategi implementasi

- Ketua pelaksana membuat satgas untuk melakukan pendataan objek

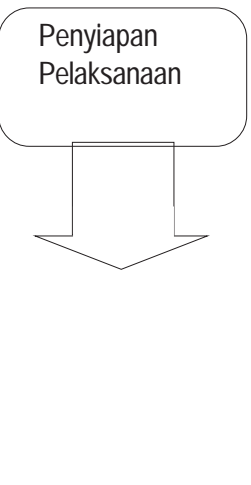

- Satagas melakukan penyiapan kegiatan inventarisasi dan identifikasi

- Satgas melakukan pengukuran dan pemetaan

- Hasil inventarisasi dan identifikasi dibuat peta bidang tanah dan daftar nominatif yang ditandatangani oleh ketua satuan tugas.

- Daftar nominatif digunakan dalam proses penentuan nilai ganti kerugian

- Satuan tugas menyelesaikan tugasnya paling lama 30 (tiga puluh) hari kerja

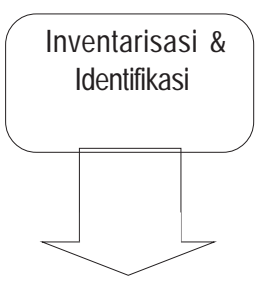

- Penetapan besarnya nilai ganti kerugian oleh ketua pelaksana berdasarkan hasil penilaian jasa penilai atau penilai publik objek

- Jasa penilai atau penilai publik ditetapkan oleh ketua pelaksana pengadaan tanah

- Nilai ganti kerugian merupakan nilai pada saat pengumuman penetapan lokasi

- Nilai ganti kerugian merupakan nilai tunggal untuk bidang per bidang tanah

- Besarnya nilai ganti kerugian dijadikan dasar musyawarah untuk menetapkan bentuk ganti kerugian.

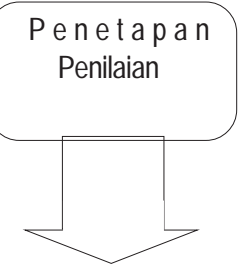

- Pelaksana musyawarah dalam waktu paling lama 30 (tiga puluh) hari kerja

- Mengikutsertakan instansi yang memerlukan tanah.

- Dilakukan secara langsung.

- Pelaksana Pengadaan tanah menyampaikan besarnya ganti kerugian hasil penilaian ganti keruggian

- Pelaksana pengadaan tanah mengundang pihak yang berhak menetapkan tempat waktu pelaksanaan.

- Undangan disampaikan paling lambat 5 (lima) hari kerja sebelum pelaksanaan musyawarah 


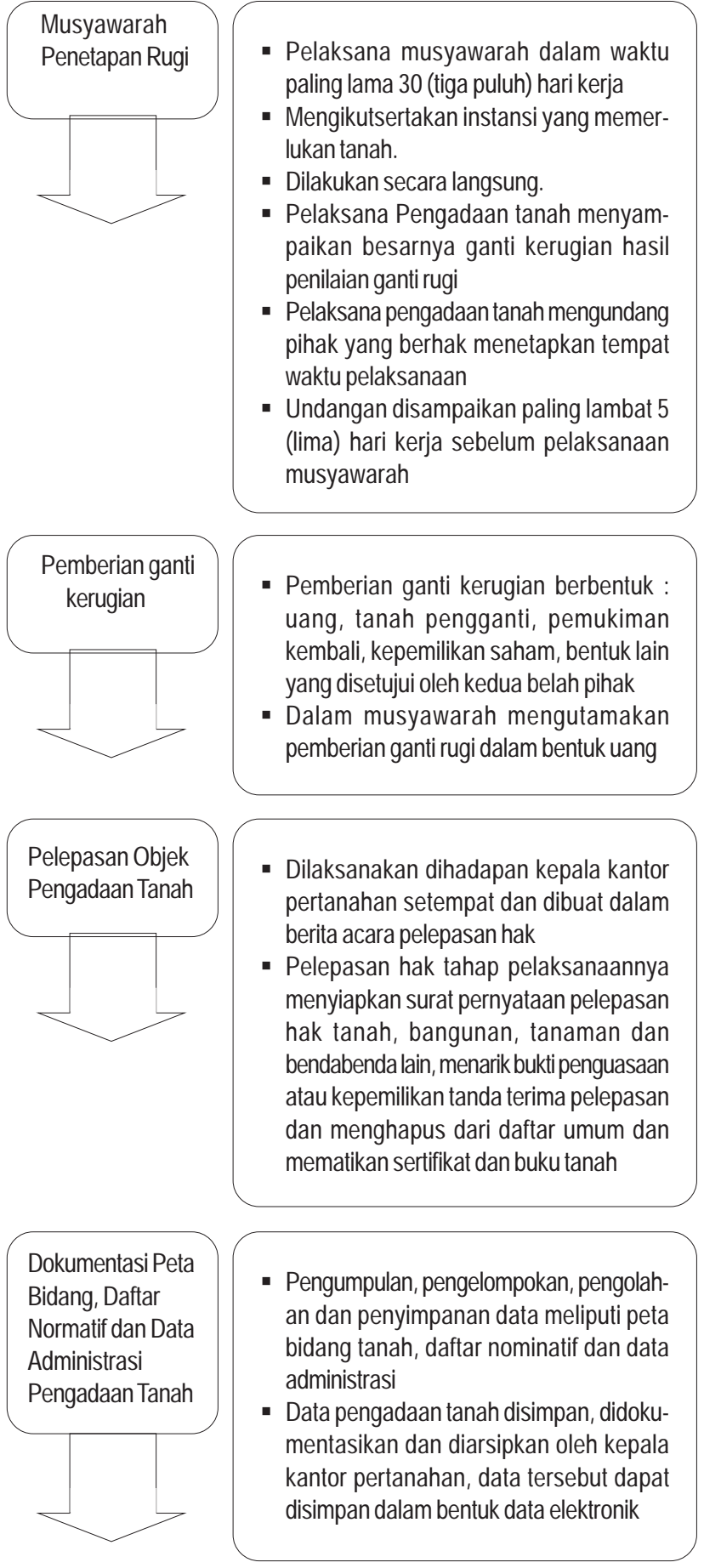

Gambar 4.3 Tahapan Pelaksanaan Republik Indonesia

\section{Penyerahan Hasil}

Serah Terima Dokumen Pengadaan Tanah Dari Pelaksana Pengadaan Tanah Kepada Instansi yang
Memerlukan Tanah, maka dimulainya Kegiatan Pembangunan

Infrastruktur oleh instansi yang membutuhkan tanah. Pembangunan Dilaksanakan oleh Pemerintah, Pemerintah Daerah, BUMN Serta Swasta Dengan Skema KPS (PPP), tahapan selanjutnya adalah Kegiatan Pendaftaran Tanah (Sertipikasi) Barang Milik Negara Berupa Tanah.

Berdasarkan keempat tahapan dari pengadaan tanah untuk kepentingan umum tersebut dapat dilihat atau dijelaskan kedalam alur sebagai berikut :

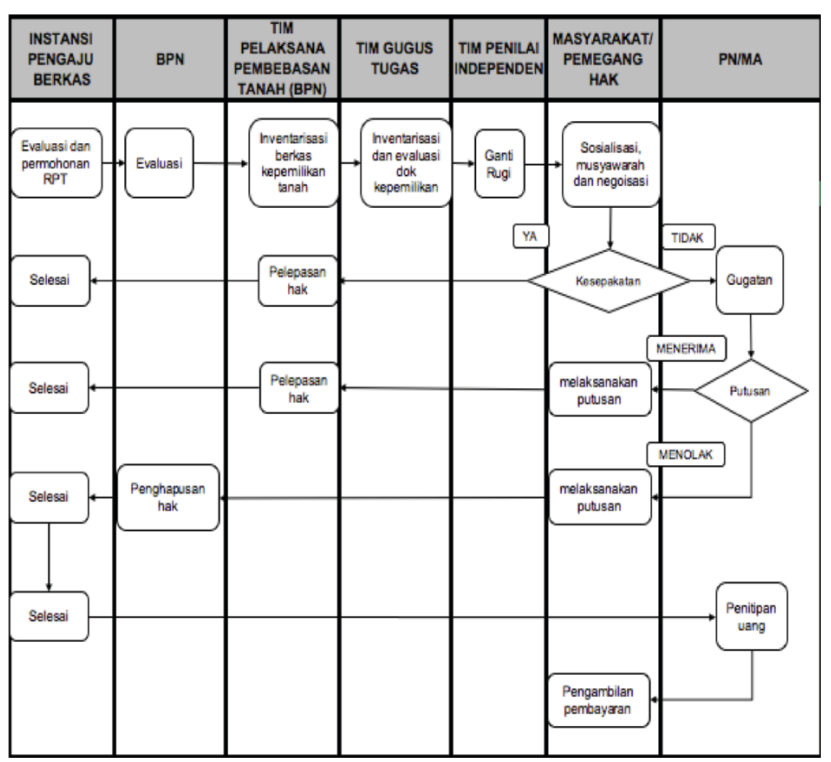

Gambar 4.4 Bagan Alur Pelaksanaan Pengadaan Tanah Untuk Kepentingan Umum (Republik Indonesia)

\section{I.2 Kejadian-Kejadian Yang Tidak Dikehendaki}

Tabel 4.I Kejadian Yang Tidak Dikehendaki

\begin{tabular}{|c|c|c|c|}
\hline NO & \multicolumn{2}{|r|}{ TAHAPAN } & KEJADIAN YANG TIDAK \\
\hline 1 & $\begin{array}{l}\text { PERENCA- } \\
\text { NAAN }\end{array}$ & Pengajuan Dokumen & $\begin{array}{l}\text { Waktu pengerjaan tidak } \\
\text { sesuai dengan tata waktu }\end{array}$ \\
\hline \multirow[t]{2}{*}{2} & \multirow[t]{2}{*}{$\begin{array}{l}\text { PERSIAP- } \\
\text { AN }\end{array}$} & $\begin{array}{l}\text { Pemberitahuan Ren- } \\
\text { cana Pembangunan }\end{array}$ & $\begin{array}{l}\text { 1. Waktu pengerjaan tidak } \\
\text { sesuai dengan tata waktu } \\
\text { 2. Muncul gejolak sosial }\end{array}$ \\
\hline & & PendataanAwal Lokasi & $\begin{array}{l}\text { 1. Waktu pengerjaan tidak } \\
\text { sesuai dengan tata waktu } \\
\text { 2. Muncul gejolak sosial }\end{array}$ \\
\hline
\end{tabular}




\begin{tabular}{|c|c|c|c|}
\hline & & Konsultasi Publik & $\begin{array}{l}\text { 1. Waktu pengerjaan tidak } \\
\text { sesuai dengan tata waktu } \\
\text { 2. Muncul gejolak sosial }\end{array}$ \\
\hline & & Penetapan Lokasi & $\begin{array}{l}\text { 1. Waktu pengerjaan tidak } \\
\text { sesuai dengan tata waktu } \\
\text { 2. Muncul gejolak sosial }\end{array}$ \\
\hline \multirow[t]{5}{*}{3} & \multirow[t]{5}{*}{$\begin{array}{l}\text { PELAKSA- } \\
\text { NAAN }\end{array}$} & $\begin{array}{l}\text { Inventarisasi dan } \\
\text { Identifikasi }\end{array}$ & $\begin{array}{l}\text { 1. Waktu pengerjaan tidak } \\
\text { sesuai dengan tata waktu } \\
\text { 2. Muncul gejolak sosial }\end{array}$ \\
\hline & & $\begin{array}{l}\text { Penilaian dan Ganti } \\
\text { Rugi }\end{array}$ & $\begin{array}{l}\text { 1. Waktu pengerjaan tidak } \\
\text { sesuai dengan tata waktu } \\
\text { 2. Muncul gejolak sosial }\end{array}$ \\
\hline & & $\begin{array}{l}\text { Musyawarah Penetap- } \\
\text { an Ganti Rugi }\end{array}$ & $\begin{array}{l}\text { 1. Waktu pengerjaan tidak } \\
\text { sesuai dengan tata waktu } \\
\text { 2. Muncul gejolak sosial }\end{array}$ \\
\hline & & Pemberian Ganti Rugi & $\begin{array}{l}\text { 1. Waktu pengerjaan tidak } \\
\text { sesuai dengan tata waktu } \\
\text { 2. Muncul gejolak sosial }\end{array}$ \\
\hline & & $\begin{array}{l}\text { Pelepasan dan pengha- } \\
\text { pusan HakAtas Tanah }\end{array}$ & $\begin{array}{l}\text { Waktu pengerjaan tidak } \\
\text { sesuai dengan tata waktu }\end{array}$ \\
\hline 4 & $\begin{array}{l}\text { PENYERAH- } \\
\text { AN HASIL }\end{array}$ & Penyerahan Hasil & $\begin{array}{l}\text { Waktu pengerjaan tidak } \\
\text { sesuai dengan tata waktu }\end{array}$ \\
\hline
\end{tabular}

\subsection{Analisis Identifikasi Pengukuran Risiko Perencanaan}

Berdasarkan distribusi kuesioner penelitian yang dibagikan kepada empat (4 orang) responden dengan subfokus identifikasi risiko "Waktu pengerjaan tidak sesuai dengan tata waktu" pada sub tahapan Pengajuan Dokumen dari tahapan Perencanaan, dan didapatkan hasil risikonya, sebagai berikut pada tabel 4.2:

\section{Dampak :}

a. Instansi yang membutuhkan lahan melakukan dispute data pengajuan tanah untuk kepentingan umum dengan kondisi dilapangan yang terlalu menyimpang.

\section{Diagram Peluang Dampak}

Berdasarkan hasil pegukuran pada tabel 4.2, dengan hasil peluang risiko sebesar 4.75 dan dampak risiko sebesar 2.5, maka nilai risiko $(P X D)$ sebesar I3.25 dan nilai risk assessment matrix nya adalah High dan dapat dijabarkan kedalam diagram peluang dampak sebagai berikut :
Tabel 4.2 Pengukuran Risiko Pada Pengajuan Dokumen Identifikasi Risiko Waktu Pengerjaan Tidak Sesuai Dengan Tata Waktu

\begin{tabular}{|c|c|c|c|c|c|}
\hline \multirow{2}{*}{$\begin{array}{l}\text { Identifikasi } \\
\text { Risiko }\end{array}$} & \multicolumn{2}{|c|}{ Peluang Risiko } & \multicolumn{2}{|c|}{ Dampak Risiko } & \multirow{2}{*}{$\begin{array}{c}\text { Risk } \\
\text { Assessment } \\
\text { Matrix }\end{array}$} \\
\hline & Verbal & $\begin{array}{l}\text { Num } \\
\text { erik }\end{array}$ & Verbal & $\begin{array}{c}\text { Num } \\
\text { erik }\end{array}$ & \\
\hline \multirow{13}{*}{$\begin{array}{l}\text { Waktu } \\
\text { pengerjaan } \\
\text { tidak } \\
\text { sesuai } \\
\text { dengan } \\
\text { tata } \\
\text { waktu }\end{array}$} & Frequent & 5 & Catastrophic & 5 & $\begin{array}{l}\text { Eksteme } \\
19,5-25\end{array}$ \\
\hline & Probable & 4 & Critical & 4 & $\begin{array}{c}\text { High } \\
12.5-19.4\end{array}$ \\
\hline & Occesional & 3 & Moderate & 3 & $\begin{array}{c}\text { Substansial } \\
9.5-12.4\end{array}$ \\
\hline & Remote & 2 & Minor & 2 & $\begin{array}{l}\text { Medium } \\
4.5-9.4\end{array}$ \\
\hline & Improbable & 1 & Negligible & 1 & Low $1-4.4$ \\
\hline & \multicolumn{5}{|c|}{ Deskriptif Jawaban Responden } \\
\hline & $\begin{array}{l}\text { Banyak } \\
\text { Responden }\end{array}$ & $\begin{array}{l}\text { Peluang } \\
\text { Risiko }\end{array}$ & $\begin{array}{l}\text { Dampak } \\
\text { Risiko }\end{array}$ & $\begin{array}{l}\text { Risiko } \\
\text { (PXD) }\end{array}$ & \\
\hline & 1 & 5 & 3 & 15 & High \\
\hline & 2 & 4 & 2 & 8 & Medium \\
\hline & 3 & 5 & 3 & 15 & High \\
\hline & 4 & 5 & 3 & 15 & High \\
\hline & \multirow[t]{2}{*}{$f / n=\%$} & 19 & 11 & 53 & \multirow[t]{2}{*}{ High } \\
\hline & & 4.75 & 2.75 & 13.5 & \\
\hline
\end{tabular}

Sumber : Diolah, 2017

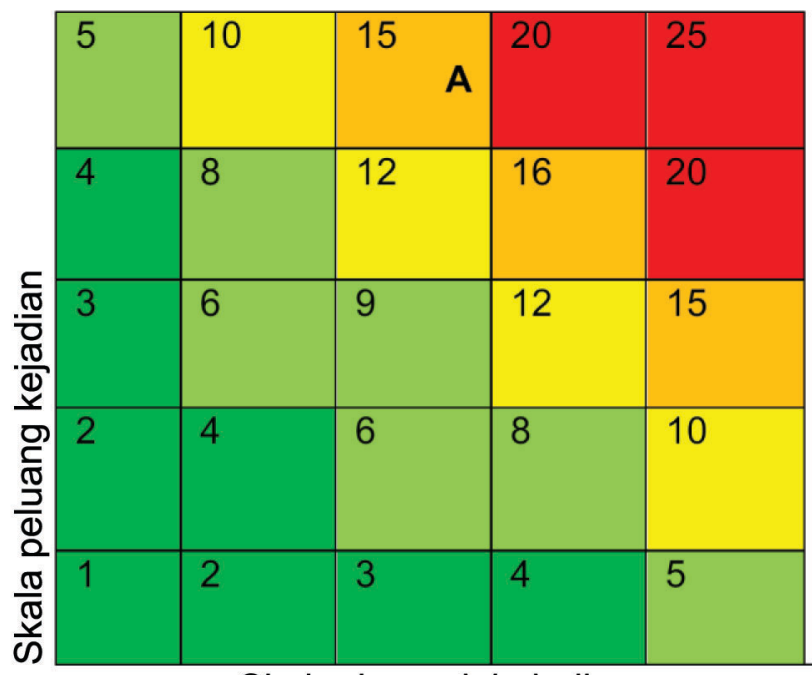

Skala dampak kejadian

Gambar 4.5 Diagram Peluang Dampak Risiko Pada Pengajuan Dokumen Identifikasi Risiko Waktu Pengerjaan Tidak Sesuai Dengan Tata Waktu 
3.Mitigasi risiko (mengecilkan peluang dan dampak risiko bagi sub tahapan Pengajuan Dokumen dari tahapan Perencanaan ) :

Survey pendahuluan ke lokasi yang dibutuhkan untuk mengumpulkan seluruh data-data yang dibutuhkan sedetail mungkin sehingga dispute data dapat di minimalisir semaksimal mungkin Analisis dan Interpretasi Identifikasi Pengukuran Risiko Persiapan.

\subsection{Analisis Identifikasi Pengukuran Risiko Persiapan}

Berdasarkan distribusi kuesioner penelitian yang dibagikan kepada empat (4 orang) responden dengan subfokus identifikasi risiko "Waktu pengerjaan tidak sesuai dengan tata waktu" pada sub tahapan Pemberitahuan Rencana Pembangunan dari tahapan Persiapan, dan didapatkan hasil risikonya, sebagai berikut:

Tabel 4.3 Pengukuran Risiko Pada Pemberitahuan Rencana Pembangunan Identifikasi Risiko Waktu Pengerjaan Tidak Sesuai Tata Waktu

\begin{tabular}{|c|c|c|c|c|c|}
\hline \multirow{2}{*}{$\begin{array}{l}\text { Identifikasi } \\
\text { Risiko }\end{array}$} & \multicolumn{2}{|c|}{ Peluang Risiko } & \multicolumn{2}{|c|}{ Dampak Risiko } & \multirow{2}{*}{$\begin{array}{c}\text { Risk } \\
\text { Assessment } \\
\text { Matrix }\end{array}$} \\
\hline & Verbal & $\begin{array}{l}\text { Num } \\
\text { erik }\end{array}$ & Verbal & $\begin{array}{c}\text { Num } \\
\text { erik }\end{array}$ & \\
\hline \multirow{13}{*}{$\begin{array}{l}\text { Waktu } \\
\text { pengerjaan } \\
\text { tidak } \\
\text { sesuai } \\
\text { dengan } \\
\text { tata } \\
\text { waktu }\end{array}$} & Frequent & 5 & Catastrophic & 5 & $\begin{array}{l}\text { Eksteme } \\
19,5-25\end{array}$ \\
\hline & Probable & 4 & Critical & 4 & $\begin{array}{c}\text { High } \\
12.5-19.4\end{array}$ \\
\hline & Occesional & 3 & Moderate & 3 & $\begin{array}{c}\text { Substansial } \\
9.5-12.4\end{array}$ \\
\hline & Remote & 2 & Minor & 2 & $\begin{array}{l}\text { Medium } \\
4.5-9.4\end{array}$ \\
\hline & Improbable & 1 & Negligible & 1 & Low $1-4.4$ \\
\hline & \multicolumn{5}{|c|}{ Deskriptif Jawaban Responden } \\
\hline & $\begin{array}{l}\text { Banyak } \\
\text { Responden }\end{array}$ & $\begin{array}{l}\text { Peluang } \\
\text { Risiko }\end{array}$ & $\begin{array}{l}\text { Dampak } \\
\text { Risiko }\end{array}$ & $\begin{array}{l}\text { Risiko } \\
\text { (PXD) }\end{array}$ & \\
\hline & 1 & 4 & 1 & 4 & Low \\
\hline & 2 & 4 & 1 & 4 & Low \\
\hline & 3 & 3 & 2 & 6 & Medium \\
\hline & 4 & 4 & 2 & 8 & Medium \\
\hline & \multirow[t]{2}{*}{$f / n=\%$} & 15 & 6 & 22 & \multirow[t]{2}{*}{ Medium } \\
\hline & & 3.75 & 1.5 & 5.5 & \\
\hline
\end{tabular}

Sumber : Diolah, 2017 I. Dampak : a. Tim Persiapan melakukan sosialisasi (Pemberitahuan Rencana Pembangunan) yang susah dimengerti maksud dan tujuannya oleh Pemilk lahan

\section{Diagram Peluang Dampak}

Berdasarkan hasil pegukuran pada tabel 4.4, dengan hasil peluang risiko sebesar 3.75 dan dampak risiko sebesar I.5, maka nilai risiko ( $P X D)$ sebesar 5.5 dan nilai risk assessment matrix nya adalah Medium dan dapat dijabarkan kedalam diagram peluang dampak sebagai berikut :

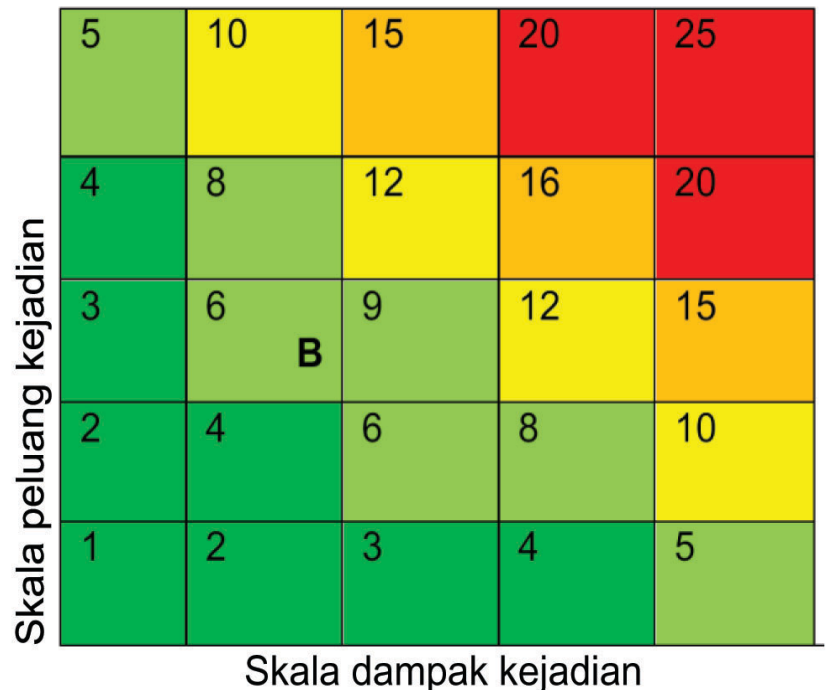

Gambar 4.6 Diagram Peluang Dampak Risiko Pada Pemberitahuan Rencana Pembangunan Identifikasi Risiko Waktu Pengerjaan Tidak Sesuai Tata Waktu

3. Mitigasi risiko (mengecilkan peluang dan dampak risiko bagi sub tahapan Pengajuan Dokumen dari tahapan Perencanaan):

Melakukan sosialisasi dengan cara penyampaian dan bahasa yang mudah dimengerti kepada masyarakat setempat, jika perlu menggunakan bahasa daerah setempat.

Berdasarkan distribusi kuesioner penelitian yang dibagikan kepada empat (4 orang) responden dengan subfokus identifikasi risiko "Muncul Gejolak Sosial” pada sub tahapan Pemberitahuan Rencana Pembangunan dari tahapan Persiapan, dan didapatkan hasil risikonya, sebagai berikut : 
Tabel 4.4 Pengukuran Risiko Pada Pemberitahuan Rencana Pembangunan Identifikasi Risiko Muncul Gejolak Sosial

\begin{tabular}{|c|c|c|c|c|c|}
\hline \multirow{2}{*}{$\begin{array}{l}\text { Identifikasi } \\
\text { Risiko }\end{array}$} & \multicolumn{2}{|c|}{ Peluang Risiko } & \multicolumn{2}{|c|}{ Dampak Risiko } & \multirow{2}{*}{\begin{tabular}{|c} 
Risk \\
Assessment \\
Matrix
\end{tabular}} \\
\hline & Verbal & $\begin{array}{l}\text { Num } \\
\text { erik }\end{array}$ & Verbal & $\begin{array}{c}\text { Num } \\
\text { erik }\end{array}$ & \\
\hline \multirow{13}{*}{$\begin{array}{l}\text { Muncul } \\
\text { gejolak } \\
\text { sosial }\end{array}$} & Frequent & 5 & Catastrophic & 5 & $\begin{array}{c}\text { Eksteme } \\
19,5-25\end{array}$ \\
\hline & Probable & 4 & Critical & 4 & $\begin{array}{c}\text { High } \\
12.5-19.4\end{array}$ \\
\hline & Occesional & 3 & Moderate & 3 & \begin{tabular}{|c|} 
Substansial \\
$9.5-12.4$
\end{tabular} \\
\hline & Remote & 2 & Minor & 2 & $\begin{array}{l}\text { Medium } \\
4.5-9.4\end{array}$ \\
\hline & Improbable & 1 & Negligible & 1 & Low $1-4.4$ \\
\hline & \multicolumn{5}{|c|}{ Deskriptif Jawaban Responden } \\
\hline & $\begin{array}{l}\text { Banyak } \\
\text { Responden }\end{array}$ & $\begin{array}{l}\text { Peluang } \\
\text { Risiko }\end{array}$ & \begin{tabular}{|l} 
Dampak \\
Risiko
\end{tabular} & $\begin{array}{l}\text { Risiko } \\
\text { (PXD) }\end{array}$ & \\
\hline & 1 & 3 & 2 & 6 & High \\
\hline & 2 & 4 & 2 & 8 & Substansial \\
\hline & 3 & 4 & 2 & 8 & High \\
\hline & 4 & 4 & 2 & 8 & High \\
\hline & \multirow[t]{2}{*}{$f / n=\%$} & 15 & 8 & 30 & \multirow[t]{2}{*}{ Medium } \\
\hline & & 3.75 & 2 & 7.5 & \\
\hline
\end{tabular}

Sumber : Diolah, 2017

\section{Diagram Peluang Dampak}

Berdasarkan hasil pegukuran pada tabel 4.4, dengan hasil peluang risiko sebesar 3.75 dan dampak risiko sebesar I.5, maka nilai risiko $(P X D)$ sebesar 5.5 dan nilai risk assessment matrix nya adalah Medium dan dapat dijabarkan kedalam diagram peluang dampak sebagai berikut :

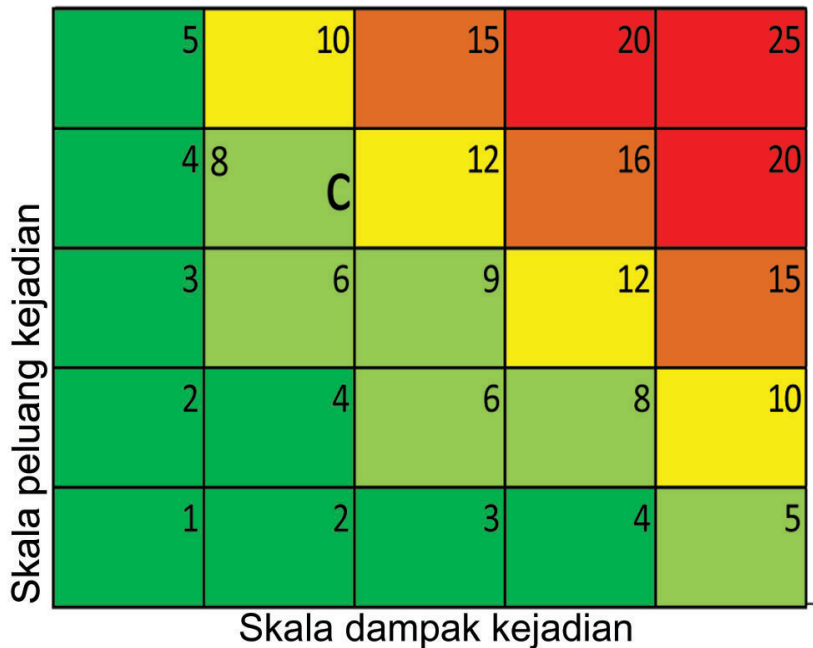

Gambar 4.7 Diagram Peluang Dampak Risiko Pada Pemberitahuan Rencana Pembangunan Identifikasi Risiko Muncul Gejolak Sosial
5. Mitigasi risiko (mengecilkan peluang dan dampak risiko bagi sub tahapan Pemberitahuan Rencanan Pembangunan dari tahapan Persiapan):

I. Melakukan sosialisasi dengan cara penyampaian dan bahasa yang mudah dimengerti kepada masyarakat setempat, jika perlu menggunakan bahasa daerah setempat.

2. Pemberitahuan Rencana Pembangunan dimediasi oleh muspika Setempat dan orang yang dituangkan oleh warga setempat untuk meminimalisir konflik yang terjadi saat Pemberitahuan Rencana Pembanguan Berlangsung.

Berdasarkan distribusi kuesioner penelitian yang dibagikan kepada empat (4 orang) responden dengan subfokus identifikasi risiko "Waktu pengerjaan tidak sesuai dengan tata waktu" pada sub tahapan Pendataan awal dari tahapan Persiapan, dan didapatkan hasil risikonya, sebagai berikut :

Tabel 4.5 Pengukuran Risiko Pada Pendataan Awal Identifikasi Risiko Waktu Pengerjaan Tidak Sesuai Dengan Tata Waktu

\begin{tabular}{|c|c|c|c|c|c|}
\hline \multirow{2}{*}{$\begin{array}{l}\text { Identifikasi } \\
\text { Risiko }\end{array}$} & \multicolumn{2}{|c|}{ Peluang Risiko } & \multicolumn{2}{|c|}{ Dampak Risiko } & \multirow{2}{*}{$\begin{array}{c}\text { Risk } \\
\text { Assessment } \\
\text { Matrix }\end{array}$} \\
\hline & Verbal & $\begin{array}{l}\text { Num } \\
\text { erik }\end{array}$ & Verbal & $\begin{array}{l}\text { Num } \\
\text { erik }\end{array}$ & \\
\hline \multirow{13}{*}{$\begin{array}{l}\text { Waktu } \\
\text { pengerjaan } \\
\text { tidak } \\
\text { sesuai } \\
\text { dengan } \\
\text { tata } \\
\text { waktu }\end{array}$} & Frequent & 5 & Catastrophic & 5 & $\begin{array}{l}\text { Eksteme } \\
19,5-25\end{array}$ \\
\hline & Probable & 4 & Critical & 4 & $\begin{array}{c}\text { High } \\
12.5-19.4\end{array}$ \\
\hline & Occesional & 3 & Moderate & 3 & \begin{tabular}{|c|} 
Substansial \\
$9.5-12.4$
\end{tabular} \\
\hline & Remote & 2 & Minor & 2 & $\begin{array}{l}\text { Medium } \\
4.5-9.4\end{array}$ \\
\hline & Improbable & 1 & Negligible & 1 & Low 1 - 4.4 \\
\hline & \multicolumn{5}{|c|}{ Deskriptif Jawaban Responden } \\
\hline & $\begin{array}{l}\text { Banyak } \\
\text { Responden }\end{array}$ & $\begin{array}{l}\text { Peluang } \\
\text { Risiko }\end{array}$ & \begin{tabular}{|l} 
Dampak \\
Risiko
\end{tabular} & $\begin{array}{l}\text { Risiko } \\
\text { (PXD) }\end{array}$ & \\
\hline & 1 & 5 & 3 & 15 & High \\
\hline & 2 & 5 & 2 & 10 & Substansial \\
\hline & 3 & 5 & 2 & 10 & Substansial \\
\hline & 4 & 5 & 3 & 15 & High \\
\hline & \multirow[t]{2}{*}{$f / n=\%$} & 20 & 10 & 50 & \multirow[t]{2}{*}{ High } \\
\hline & & 5 & 2.5 & 12.5 & \\
\hline
\end{tabular}

Sumber : Diolah, 2017 
I. Dampak:

a. Tim Persiapan melakukan dispute data kepemilikan tanah yang ingin dibebaskan

b. Pemilik lahan tidak mengerti akan maksud dan tujuan penjelasan/sosialisasi dari pemberitahuan rencana pembangunan oleh tim persiapan

2. Diagram Peluang Dampak

Berdasarkan hasil pegukuran pada tabel 4.8, dengan hasil peluang risiko sebesar 5 dan dampak risiko sebesar 2.5, maka nilai risiko $(P \times D)$ sebesar 12.25 dan nilai risk assessment matrix nya adalah High dan dapat dijabarkan kedalam diagram peluang dampak sebagai berikut :

Skla Peluang kejadian

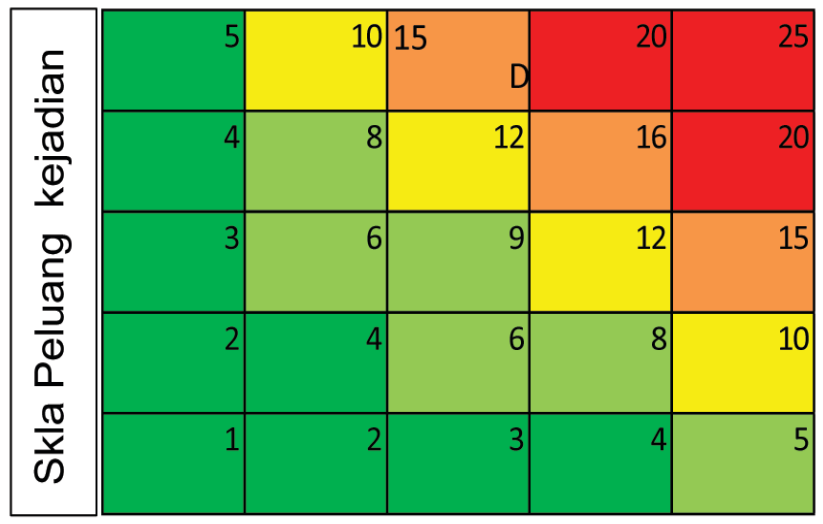

Skala dampak kejadian

Gambar 4.8 Diagram Peluang Dampak Risiko Pada Pendataan Awal IdentifikasiRisiko Waktu Pengerjaan Tidak Sesuai Dengan Tata Waktu

3. Mitigasi risiko (mengecilkan peluang dan dampak risiko bagi sub tahapan Pendataan Awal dari tahapan Persiapan) :

I. Melakukan sosialisasi dengan cara penyampaian dan bahasa yang mudah dimengerti kepada masyarakat setempat, jika perlu menggunakan bahasa daerah setempat.

2. Pemberitahuan Rencana Pembangunan dimediasi oleh muspika Setempat dan orang yang dituangkan oleh warga setempat untuk meminimalisir konflik yang terjadi saat Pemberitahuan Rencana Pembanguan Berlangsung.
Berdasarkan distribusi kuesioner penelitian yang dibagikan kepada empat (4 orang) responden dengan subfokus identifikasi risiko "Muncul gejolak sosial” pada sub tahapan Pendataan awal dari tahapan Persiapan, dan didapatkan hasil risikonya, sebagai berikut:

Tabel 4.6 Pengukuran Risiko Pada Pendataan Awal Identifikasi Risiko Muncul Gejolak Sosial

\begin{tabular}{|c|c|c|c|c|c|}
\hline \multirow{2}{*}{$\begin{array}{l}\text { Identifikasi } \\
\text { Risiko }\end{array}$} & \multicolumn{2}{|c|}{ Peluang Risiko } & \multicolumn{2}{|c|}{ Dampak Risiko } & \multirow{2}{*}{$\begin{array}{c}\text { Risk } \\
\text { Assessment } \\
\text { Matrix }\end{array}$} \\
\hline & Verbal & $\begin{array}{l}\text { Num } \\
\text { erik }\end{array}$ & Verbal & \begin{tabular}{|c|} 
Num \\
erik
\end{tabular} & \\
\hline \multirow{13}{*}{$\begin{array}{l}\text { Muncul } \\
\text { gejolak } \\
\text { sosial }\end{array}$} & Frequent & 5 & Catastrophic & 5 & $\begin{array}{l}\text { Eksteme } \\
19,5-25\end{array}$ \\
\hline & Probable & 4 & Critical & 4 & $\begin{array}{c}\text { High } \\
12.5-19.4\end{array}$ \\
\hline & Occesional & 3 & Moderate & 3 & \begin{tabular}{|c} 
Substansial \\
$9.5-12.4$
\end{tabular} \\
\hline & Remote & 2 & Minor & 2 & $\begin{array}{l}\text { Medium } \\
4.5-9.4\end{array}$ \\
\hline & Improbable & 1 & Negligible & 1 & Low 1 - 4.4 \\
\hline & \multicolumn{5}{|c|}{ Deskriptif Jawaban Responden } \\
\hline & $\begin{array}{l}\text { Banyak } \\
\text { Responden }\end{array}$ & $\begin{array}{l}\text { Peluang } \\
\text { Risiko }\end{array}$ & $\begin{array}{l}\text { Dampak } \\
\text { Risiko }\end{array}$ & $\begin{array}{l}\text { Risiko } \\
\text { (PXD) } \\
\end{array}$ & \\
\hline & 1 & 5 & 3 & 15 & High \\
\hline & 2 & 4 & 3 & 12 & High \\
\hline & 3 & 5 & 3 & 15 & High \\
\hline & 4 & 5 & 2 & 10 & Substansial \\
\hline & \multirow[t]{2}{*}{$f / n=\%$} & 19 & 11 & 52 & \multirow[t]{2}{*}{ High } \\
\hline & & 4.75 & 2.75 & 13 & \\
\hline
\end{tabular}

Sumber : Diolah, 2017

I. Dampak:

a. Tim Persiapan melakukan dispute data kepemilikan tanah yang ingin dibebaskan 2. Diagram Peluang Dampak

Berdasarkan hasil pegukuran pada tabel 4.10, dengan hasil peluang risiko sebesar 4.75 dan dampak risiko sebesar 2.75, maka nilai risiko $(P X D)$ sebesar I 3 dan nilai risk assessment matrix nya adalah High dan dapat dijabarkan kedalam diagram peluang dampak sebagai berikut : 


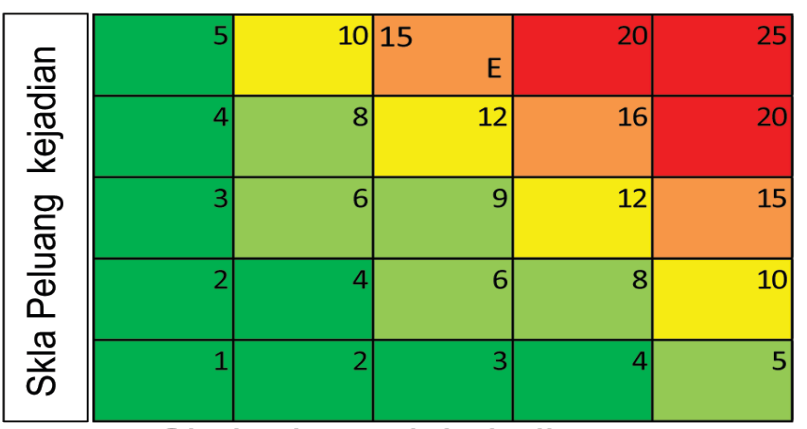

Skala dampak kejadian

Gambar 4.9 Diagram Peluang Dampak Risiko Pada Pendataan Awal Identifikasi Risiko Muncul Gejolak Sosial

3. Mitigasi risiko (mengecilkan peluang dan dampak risiko bagi sub tahapan Pendataan Awal dari tahapan Persiapan) :

Berdasarkan distribusi kuesioner penelitian yang dibagikan kepada empat (4 orang) responden dengan subfokus identifikasi risiko "Waktu pengerjaan tidak sesuai dengan tata waktu" pada sub tahapan Konsultasi Publik dari tahapan Persiapan, dan didapatkan hasil risikonya, sebagai berikut :

Tabel 4.7 Pengukuran Risiko Pada Konsultasi Publik Identifikasi Risiko Waktu Pengerjaan Tidak Sesuai Dengan Tata Waktu

\begin{tabular}{|c|c|c|c|c|c|}
\hline \multirow{2}{*}{$\begin{array}{l}\text { Identifikasi } \\
\text { Risiko }\end{array}$} & \multicolumn{2}{|c|}{ Peluang Risiko } & \multicolumn{2}{|c|}{ Dampak Risiko } & \multirow{2}{*}{$\begin{array}{c}\text { Risk } \\
\text { Assessment } \\
\text { Matrix }\end{array}$} \\
\hline & Verbal & $\begin{array}{l}\text { Num } \\
\text { erik }\end{array}$ & Verbal & \begin{tabular}{|c|} 
Num \\
erik
\end{tabular} & \\
\hline \multirow{13}{*}{$\begin{array}{l}\text { Waktu } \\
\text { pengerjaan } \\
\text { tidak } \\
\text { sesuai } \\
\text { dengan } \\
\text { tata } \\
\text { waktu }\end{array}$} & Frequent & 5 & Catastrophic & 5 & $\begin{array}{c}\text { Eksteme } \\
19,5-25\end{array}$ \\
\hline & Probable & 4 & Critical & 4 & $\begin{array}{c}\text { High } \\
12.5-19.4\end{array}$ \\
\hline & Occesional & 3 & Moderate & 3 & \begin{tabular}{|c|} 
Substansial \\
$9.5-12.4$
\end{tabular} \\
\hline & Remote & 2 & Minor & 2 & $\begin{array}{l}\text { Medium } \\
4.5-9.4 \\
\end{array}$ \\
\hline & Improbable & 1 & Negligible & 1 & Low $1-4.4$ \\
\hline & \multicolumn{5}{|c|}{ Deskriptif Jawaban Responden } \\
\hline & $\begin{array}{l}\text { Banyak } \\
\text { Responden }\end{array}$ & $\begin{array}{l}\text { Peluang } \\
\text { Risiko }\end{array}$ & $\begin{array}{l}\text { Dampak } \\
\text { Risiko }\end{array}$ & $\begin{array}{l}\text { Risiko } \\
\text { (PXD) }\end{array}$ & \\
\hline & 1 & 5 & 3 & 15 & High \\
\hline & 2 & 4 & 3 & 12 & Substansial \\
\hline & 3 & 5 & 3 & 15 & High \\
\hline & 4 & 5 & 3 & 15 & high \\
\hline & \multirow[t]{2}{*}{$f / n=\%$} & 19 & 12 & 57 & \multirow[t]{2}{*}{ High } \\
\hline & & 4.75 & 3 & 14.25 & \\
\hline
\end{tabular}

Sumber : Diolah, 2017
I. Dampak :

a. Tim Persiapan melakukan dispute data kepemilikan tanah yang ingin dibebaskan 2. Diagram Peluang Dampak

Berdasarkan hasil pegukuran pada tabel 4.12, dengan hasil peluang risiko sebesar 4.75 dan dampak risiko sebesar 3, maka nilai risiko ( $P \times D$ ) sebesar 14.25 dan nilai risk assessment matrix nya adalah High dan dapat dijabarkan kedalam diagram peluang dampak sebagai berikut :
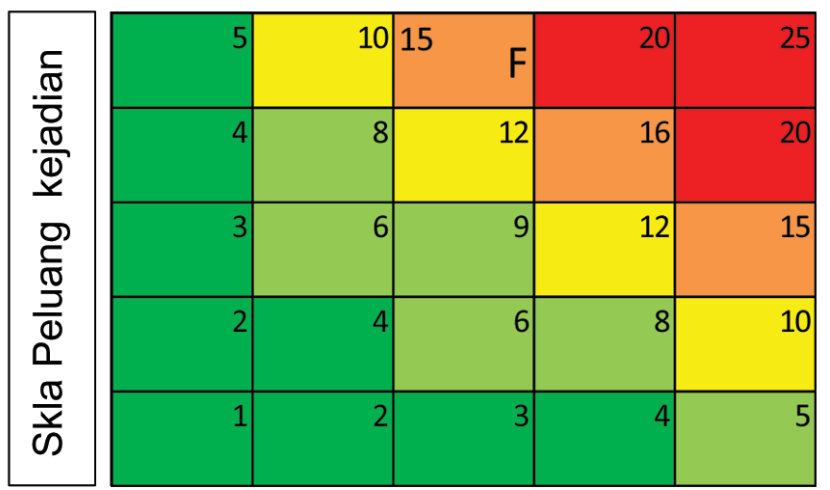

Skala dampak kejadian

Gambar 4.IOn Diagram Peluang Dampak Risiko Pada Konsultasi Publik Identifikasi Risiko Waktu Pengerjaan Tidak Sesuai Dengan Tata Waktu

3. Mitigasi risiko (mengecilkan peluang dan dampak risiko bagi sub tahapan Konsultasi Publik dari tahapan Persiapan) :

I Tim Persiapan berkoordinasi dengan muspika selaku wakil pemerintah daerah terkecil seharusnya memiliki data kepemilikan tanah masyarakat setempat yang selalu terupdate, terupdate yang dimaksud adalah kepemilikan tanah warga benar secara hukum keabsahannya, dan apabila tanah tersebut telah diperjualbelikan muspika mengetahuinya dan memiliki copy berkas jual beli

2 Melakukan sosialisasi dengan cara penyampaian dan bahasa yang mudah dimengerti kepada masyarakat setempat, jika perlu menggunakan bahasa daerah setempat.

Berdasarkan distribusi kuesioner penelitian yang dibagikan kepada empat (4 orang) responden dengan 
subfokus identifikasi risiko "Muncul gejolak sosial" pada sub tahapan Konsultasi Publik dari tahapan Persiapan, dan didapatkan hasil risikonya, sebagai berikut:

Tabel 4.8 Pengukuran Risiko Pada Konsultasi Publik Identifikasi Risiko Muncul Gejolak Sosial

\begin{tabular}{|c|c|c|c|c|c|}
\hline \multirow{2}{*}{$\begin{array}{l}\text { Identifikasi } \\
\text { Risiko }\end{array}$} & \multicolumn{2}{|c|}{ Peluang Risiko } & \multicolumn{2}{|c|}{ Dampak Risiko } & \multirow{2}{*}{$\begin{array}{c}\text { Risk } \\
\text { Assessment } \\
\text { Matrix }\end{array}$} \\
\hline & Verbal & $\begin{array}{l}\text { Num } \\
\text { erik }\end{array}$ & Verbal & $\begin{array}{c}\text { Num } \\
\text { erik }\end{array}$ & \\
\hline \multirow{13}{*}{$\begin{array}{l}\text { Muncul } \\
\text { gejolak } \\
\text { sosial }\end{array}$} & Frequent & 5 & Catastrophic & 5 & $\begin{array}{l}\text { Eksteme } \\
19,5-25\end{array}$ \\
\hline & Probable & 4 & Critical & 4 & $\begin{array}{c}\text { High } \\
12.5-19.4\end{array}$ \\
\hline & Occesional & 3 & Moderate & 3 & $\begin{array}{c}\text { Substansial } \\
9.5-12.4\end{array}$ \\
\hline & Remote & 2 & Minor & 2 & $\begin{array}{l}\text { Medium } \\
4.5-9.4\end{array}$ \\
\hline & Improbable & 1 & Negligible & 1 & Low 1 - 4.4 \\
\hline & \multicolumn{5}{|c|}{ Deskriptif Jawaban Responden } \\
\hline & $\begin{array}{l}\text { Banyak } \\
\text { Responden }\end{array}$ & $\begin{array}{l}\text { Peluang } \\
\text { Risiko }\end{array}$ & $\begin{array}{l}\text { Dampak } \\
\text { Risiko }\end{array}$ & $\begin{array}{l}\text { Risiko } \\
\text { (PXD) }\end{array}$ & \\
\hline & 1 & 5 & 3 & 15 & High \\
\hline & 2 & 5 & 3 & 12 & Substansial \\
\hline & 3 & 5 & 4 & 20 & Ekstreme \\
\hline & 4 & 5 & 2 & 10 & Substansial \\
\hline & \multirow[t]{2}{*}{$f / n=\%$} & 20 & 10 & 57 & \multirow[t]{2}{*}{ High } \\
\hline & & 5 & 2.5 & 14.25 & \\
\hline
\end{tabular}

Sumber : Diolah, 2017

I. Dampak:

a. Tim Persiapan melakukan dispute data kepemilikan tanah yang ingin dibebaskan

b. Pemilik lahan tidak menghadiri kegiatan Konsultasi Publik dikarenakan tidak sampainya undangan, dan pemilik lahan tidak mengerti maksud dan tujuan yang diutarakan oleh tim persiapan

2. Diagram Peluang Dampak

Berdasarkan hasil pegukuran pada tabel 4.14, dengan hasil peluang risiko sebesar 4.75 dan dampak risiko sebesar 2.75, maka nilai risiko ( $P$ $X \mathrm{D})$ sebesar 12.25 dan nilai risk assessment matrix nya adalah High dan dapat dijabarkan kedalam diagram peluang dampak sebagai berikut :

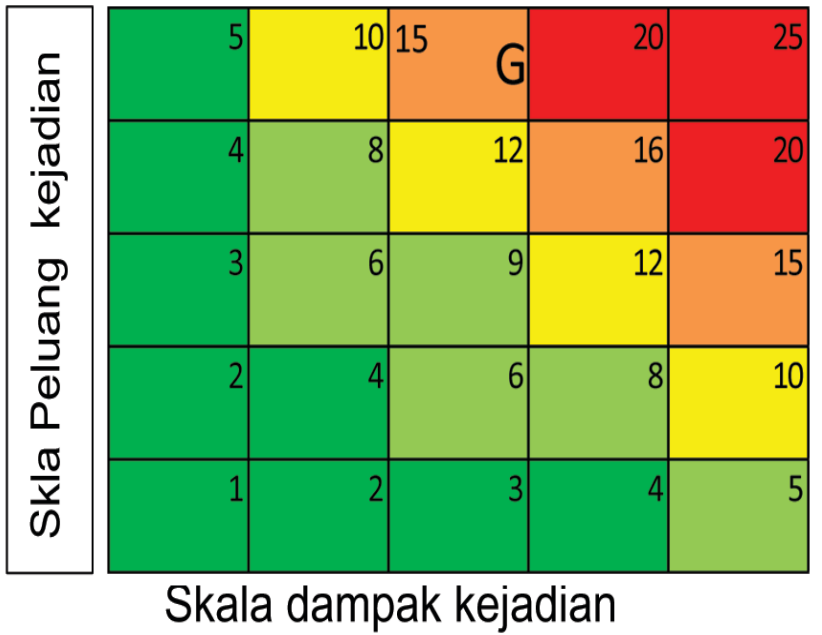

Gambar 4.II Diagram Peluang Dampak Risiko Pada Konsultasi Publik Identifikasi Risiko Muncul Gejolak Sosial

3. Mitigasi risiko (mengecilkan peluang dan dampak risiko bagi sub tahapan Konsultasi Publik dari tahapan Persiapan) :

I. Tim Persiapan berkoordinasi dengan muspika selaku wakil pemerintah daerah terkecil seharusnya memiliki data kepemilikan tanah masyarakat setempat yang selalu terupdate, terupdate yang dimaksud adalah kepemilikan tanah warga benar secara hukum keabsahannya, dan apabila tanah tersebut telah diperjualbelikan muspika mengetahuinya dan memiliki copy berkas jual beli

2. Melakukan sosialisasi dengan cara penyampaian dan bahasa yang mudah dimengerti kepada masyarakat setempat, jika perlu menggunakan bahasa daerah setempat dan dimediasi oleh muspika setempat serta orang yang dituakan oleh warga setempat

Berdasarkan distribusi kuesioner penelitian yang dibagikan kepada empat (4 orang) responden dengan subfokus identifikasi risiko "Waktu pengerjaan tidak sesuai dengan tata waktu" pada sub tahapan Penetapan Lokasi dari tahapan Persiapan, dan didapatkan hasil risikonya, sebagai berikut : 
Tabel 4.9 Pengukuran Risiko Pada Penetapan Lokasi Identifikasi Risiko Waktu Pengerjaan Tidak Sesuai Dengan Tata Waktu

\begin{tabular}{|c|c|c|c|c|c|}
\hline \multirow{2}{*}{$\begin{array}{l}\text { Identifikasi } \\
\text { Risiko }\end{array}$} & \multicolumn{2}{|c|}{ Peluang Risiko } & \multicolumn{2}{|c|}{ Dampak Risiko } & \multirow{2}{*}{$\begin{array}{c}\text { Risk } \\
\text { Assessment } \\
\text { Matrix }\end{array}$} \\
\hline & Verbal & $\begin{array}{l}\text { Num } \\
\text { erik }\end{array}$ & Verbal & $\begin{array}{c}\text { Num } \\
\text { erik }\end{array}$ & \\
\hline \multirow{13}{*}{$\begin{array}{l}\text { Waktu } \\
\text { pengerjaan } \\
\text { tidak } \\
\text { sesuai } \\
\text { dengan } \\
\text { tata } \\
\text { waktu }\end{array}$} & Frequent & 5 & Catastrophic & 5 & $\begin{array}{c}\text { Eksteme } \\
19,5-25\end{array}$ \\
\hline & Probable & 4 & Critical & 4 & $\begin{array}{c}\text { High } \\
12.5-19.4\end{array}$ \\
\hline & Occesional & 3 & Moderate & 3 & $\begin{array}{c}\text { Substansial } \\
9.5-12.4\end{array}$ \\
\hline & Remote & 2 & Minor & 2 & $\begin{array}{l}\text { Medium } \\
4.5-9.4\end{array}$ \\
\hline & Improbable & 1 & Negligible & 1 & Low $1-4.4$ \\
\hline & \multicolumn{5}{|c|}{ Deskriptif Jawaban Responden } \\
\hline & $\begin{array}{l}\text { Banyak } \\
\text { Responden }\end{array}$ & $\begin{array}{l}\text { Peluang } \\
\text { Risiko }\end{array}$ & $\begin{array}{l}\text { Dampak } \\
\text { Risiko }\end{array}$ & $\begin{array}{l}\text { Risiko } \\
\text { (PXD) }\end{array}$ & \\
\hline & 1 & 4 & 2 & 8 & Medium \\
\hline & 2 & 4 & 2 & 8 & Medium \\
\hline & 3 & 3 & 1 & 3 & Low \\
\hline & 4 & 4 & 2 & 8 & Medium \\
\hline & \multirow[t]{2}{*}{$f / n=\%$} & 15 & 7 & 27 & \multirow[t]{2}{*}{ Medium } \\
\hline & & 3.75 & 1.75 & 6.75 & \\
\hline
\end{tabular}

Sumber : Diolah, 2017

I. Dampak:

a. Tim Persiapan melakukan dispute data kepemilikan tanah yang ingin dibebaskan

2. Diagram Peluang Dampak

Berdasarkan hasil pegukuran pada tabel 4.16, dengan hasil peluang risiko sebesar 3.75 dan dampak risiko sebesar 3, maka nilai risiko ( $P X D)$ sebesar 6.75 dan nilai risk assessment matrix nya adalah Medium dan dapat dijabarkan kedalam diagram peluang dampak sebagai berikut :

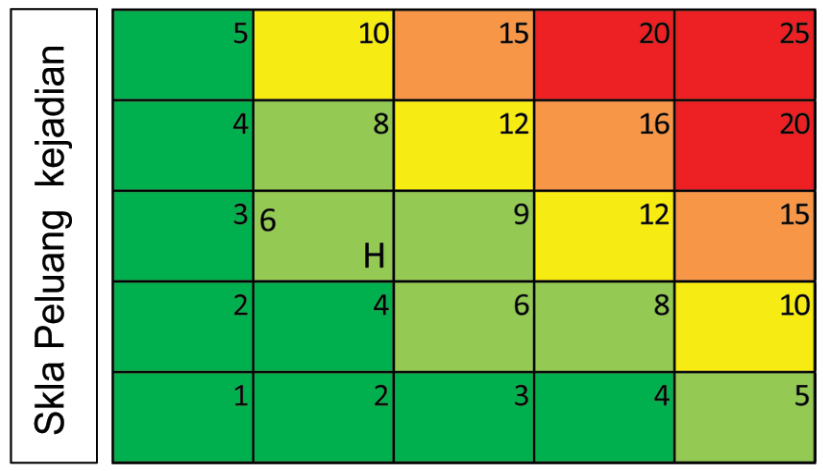

Skala dampak kejadian

Gambar 4. 2 Diagram Peluang Dampak Risiko Pada Penetapan Lokasi Identifikasi Risiko Waktu Pengerjaan Tidak Sesuai Dengan Tata Waktu
3. Mitigasi risiko (mengecilkan peluang dan dampak risiko bagi sub tahapan Penetapan Lokasi dari tahapan Persiapan) :

Tim Persiapan berkoordinasi dengan muspika selaku wakil pemerintah daerah terkecil seharusnya memiliki data kepemilikan tanah masyarakat setempat yang selalu terupdate, terupdate yang dimaksud adalah kepemilikan tanah warga benar secara hukum keabsahannya, dan apabila tanah tersebut telah diperjualbelikan muspika mengetahuinya dan memiliki copy berkas jual beli.

Berdasarkan distribusi kuesioner penelitian yang dibagikan kepada empat (4 orang) responden dengan subfokus identifikasi risiko "Muncul gejolak sosial" pada sub tahapan Penetapan Lokasi dari tahapan Persiapan, dan didapatkan hasil risikonya, sebagai berikut:

Tabel 4. I0 Pengukuran Risiko Pada Penetapan Lokasi Identifikasi Risiko Muncul Gejolak Sosial

\begin{tabular}{|c|c|c|c|c|c|}
\hline \multirow{2}{*}{$\begin{array}{l}\text { Identifikasi } \\
\text { Risiko }\end{array}$} & \multicolumn{2}{|c|}{ Peluang Risiko } & \multicolumn{2}{|c|}{ Dampak Risiko } & \multirow{2}{*}{$\begin{array}{c}\text { Risk } \\
\text { Assessment } \\
\text { Matrix }\end{array}$} \\
\hline & Verbal & $\begin{array}{l}\text { Num } \\
\text { erik }\end{array}$ & Verbal & $\begin{array}{c}\text { Num } \\
\text { erik }\end{array}$ & \\
\hline \multirow{13}{*}{$\begin{array}{l}\text { Muncul } \\
\text { gejolak } \\
\text { sosial }\end{array}$} & Frequent & 5 & Catastrophic & 5 & $\begin{array}{l}\text { Eksteme } \\
19,5-25\end{array}$ \\
\hline & Probable & 4 & Critical & 4 & $\begin{array}{c}\text { High } \\
12.5-19.4\end{array}$ \\
\hline & Occesional & 3 & Moderate & 3 & $\begin{array}{l}\text { Substansial } \\
9.5-12.4\end{array}$ \\
\hline & Remote & 2 & Minor & 2 & $\begin{array}{l}\text { Medium } \\
4.5-9.4\end{array}$ \\
\hline & Improbable & 1 & Negligible & 1 & Low $1-4.4$ \\
\hline & \multicolumn{5}{|c|}{ Deskriptif Jawaban Responden } \\
\hline & $\begin{array}{l}\text { Banyak } \\
\text { Responden }\end{array}$ & $\begin{array}{l}\text { Peluang } \\
\text { Risiko }\end{array}$ & $\begin{array}{l}\text { Dampak } \\
\text { Risiko }\end{array}$ & $\begin{array}{l}\text { Risiko } \\
\text { (PXD) }\end{array}$ & \\
\hline & 1 & 4 & 1 & 4 & Low \\
\hline & 2 & 3 & 2 & 6 & Medium \\
\hline & 3 & 4 & 2 & 8 & Medium \\
\hline & 4 & 4 & 2 & 8 & Medium \\
\hline & \multirow[b]{2}{*}{$f / n=\%$} & 15 & 7 & 26 & \\
\hline & & 3.75 & 1.75 & 6.5 & Medium \\
\hline
\end{tabular}

Sumber : Diolah, 2017 
I. Dampak:

a. Tim Persiapan melakukan dispute data kepemilikan tanah yang ingin dibebaskan

2. Diagram Peluang Dampak

Berdasarkan hasil pengukuran pada tabel 4.18, dengan hasil peluang risiko sebesar 3.75 dan dampak risiko sebesar 1.75 , maka nilai risiko $(\mathrm{P}$ $X \mathrm{D})$ sebesar 6.5 dan nilai risk assessment matrix nya adalah Medium dan dapat dijabarkan kedalam diagram peluang dampak sebagai berikut :

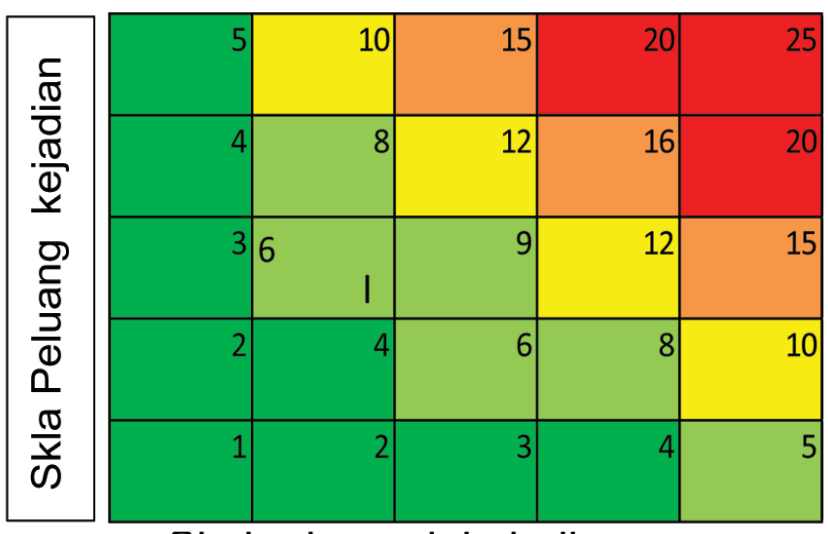

Skala dampak kejadian

Gambar 4.12 Diagram Peluang Dampak Risiko Pada Penetapan Lokasi Identifikasi Risiko Waktu Pengerjaan Tidak Sesuai Dengan Tata Waktu

I. Mitigasi risiko (mengecilkan peluang dan dampak risiko bagi sub tahapan Penetapan Lokasi dari tahapan Persiapan) :

Melakukan sosialisasi dengan cara penyampaian dan bahasa yang mudah dimengerti kepada masyarakat setempat, jika perlu menggunakan bahasa daerah setempat dan dimediasi oleh muspika setempat serta orang yang dituakan oleh warga setempat.

\subsection{Analisis Identifikasi Pengukuran Risiko Pelaksanaan}

Berdasarkan distribusi kuesioner penelitian yang dibagikan kepada empat (4 orang) responden dengan subfokus identifikasi risiko "Waktu pengerjaan tidak sesuai dengan tata waktu" pada sub tahapan Inventarisasi dan Identifikasi dari tahapan Pelaksanaan, dan didapatkan hasil risikonya, sebagai berikut :

\section{I I Pengukuran Risiko Pada Inventarisasi Dan Identifikasi Identifikasi Risiko Waktu Pengerjaan Tidak Sesuai Dengan Tata Waktu}

\begin{tabular}{|c|c|c|c|c|c|}
\hline \multirow{2}{*}{$\begin{array}{l}\text { Identifikasi } \\
\text { Risiko }\end{array}$} & \multicolumn{2}{|c|}{ Peluang Risiko } & \multicolumn{2}{|c|}{ Dampak Risiko } & \multirow{2}{*}{$\begin{array}{c}\text { Risk } \\
\text { Assessment } \\
\text { Matrix }\end{array}$} \\
\hline & Verbal & $\begin{array}{l}\text { Num } \\
\text { erik }\end{array}$ & Verbal & $\begin{array}{c}\text { Num } \\
\text { erik }\end{array}$ & \\
\hline \multirow{13}{*}{$\begin{array}{l}\text { Waktu } \\
\text { pengerjaan } \\
\text { tidak } \\
\text { sesuai } \\
\text { dengan } \\
\text { tata } \\
\text { waktu }\end{array}$} & Frequent & 5 & Catastrophic & 5 & $\begin{array}{l}\text { Eksteme } \\
19,5-25\end{array}$ \\
\hline & Probable & 4 & Critical & 4 & $\begin{array}{c}\text { High } \\
12.5-19.4\end{array}$ \\
\hline & Occesional & 3 & Moderate & 3 & $\begin{array}{c}\text { Substansial } \\
9.5-12.4\end{array}$ \\
\hline & Remote & 2 & Minor & 2 & $\begin{array}{l}\text { Medium } \\
4.5-9.4\end{array}$ \\
\hline & Improbable & 1 & Negligible & 1 & Low 1 - 4.4 \\
\hline & \multicolumn{5}{|c|}{ Deskriptif Jawaban Responden } \\
\hline & $\begin{array}{l}\text { Banyak } \\
\text { Responden }\end{array}$ & $\begin{array}{l}\text { Peluang } \\
\text { Risiko }\end{array}$ & $\begin{array}{l}\text { Dampak } \\
\text { Risiko }\end{array}$ & $\begin{array}{l}\text { Risiko } \\
\text { (PXD) }\end{array}$ & \\
\hline & 1 & 1 & 2 & 2 & Low \\
\hline & 2 & 1 & 1 & 1 & Low \\
\hline & 3 & 2 & 2 & 4 & Low \\
\hline & 4 & 2 & 2 & 4 & Low \\
\hline & \multirow[t]{2}{*}{$f / n=\%$} & 6 & 7 & 11 & \multirow[t]{2}{*}{ Low } \\
\hline & & 1.5 & 1.75 & 2.75 & \\
\hline
\end{tabular}

Sumber : Diolah, 2017

I. Dampak:

a. Tim Pelaksanaan melakukan dispute data kepemilikan tanah yang ingin dibebaskan

b. Tim Pelaksanaan melakukan kesalahan pengukuran tanah milik warga yang dibutuhkan untuk pengadaaan lahan untuk kepentingan umum

2. Diagram Peluang Dampak

Berdasarkan hasil pegukuran pada tabel 4.20, dengan hasil peluang risiko sebesar 1.5 dan dampak risiko sebesar 1.75, maka nilai risiko $(P$ $X \mathrm{D})$ sebesar 2.75 dan nilai risk assessment matrix nya adalah Low dan dapat dijabarkan kedalam diagram peluang dampak sebagai berikut : 


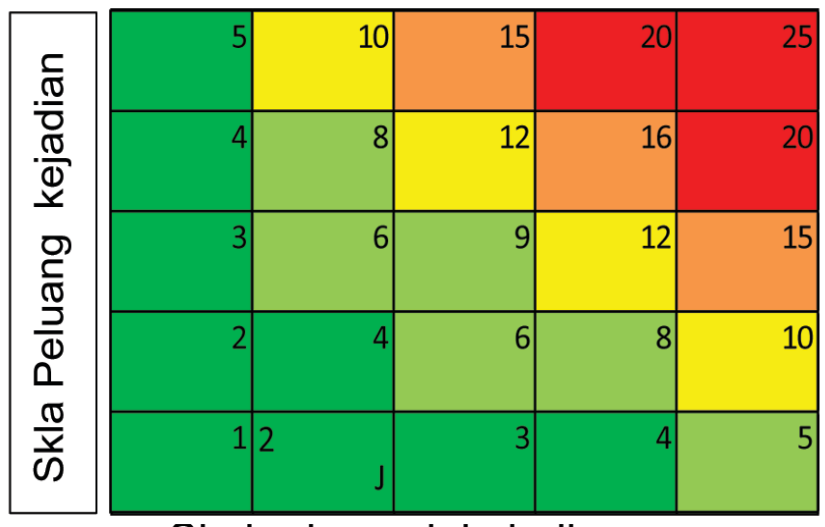

Skala dampak kejadian

Gambar 4.I3 Diagram Peluang Dampak Risiko Pada Penetapan Lokasi Identifikasi Risiko Muncul Gejolak Sosial

3. Mitigasi risiko (mengecilkan peluang dan dampak risiko bagi sub tahapan tahapan Inventarisasi dan Identifikasi dari tahapan Pelaksanaan):

I. Tim Persiapan berkoordinasi dengan muspika selaku wakil pemerintah daerah terkecil seharusnya memiliki data kepemilikan tanah masyarakat setempat yang selalu terupdate, terupdate yang dimaksud adalah kepemilikan tanah warga benar secara hukum keabsahannya, dan apabila tanah tersebut telah diperjualbelikan muspika mengetahuinya dan memiliki copy berkas jual beli

Tim pelaksanaan merupakan tim yang terdiri dari orang-orang yang berkompeten dibidangnya. Dan inventarisasi \& identifikasi dilakukan secara tidak terburu-buru (tidak satu waktu)

Berdasarkan distribusi kuesioner penelitian yang dibagikan kepada empat (4 orang) responden dengan subfokus identifikasi risiko "Muncul gejolak sosial" pada sub tahapan Inventarisasi dan Identifikasi dari tahapan Pelaksanaan, dan didapatkan hasil risikonya, sebagai berikut:

\section{I 2 Pengukuran Risiko Pada Inventarisasi Dan Identifikasi Identifikasi Risiko Muncul Gejolak Sosial}

\begin{tabular}{|c|c|c|c|c|c|}
\hline \multirow{2}{*}{$\begin{array}{l}\text { Identifikasi } \\
\text { Risiko }\end{array}$} & \multicolumn{2}{|c|}{ Peluang Risiko } & \multicolumn{2}{|c|}{ Dampak Risiko } & \multirow{2}{*}{$\begin{array}{c}\text { Risk } \\
\text { Assessmen } \\
\text { Matrix }\end{array}$} \\
\hline & Verbal & $\begin{array}{l}\text { Num } \\
\text { erik }\end{array}$ & Verbal & $\begin{array}{l}\text { Num } \\
\text { erik }\end{array}$ & \\
\hline \multirow{13}{*}{$\begin{array}{l}\text { Muncul } \\
\text { gejolak } \\
\text { sosial }\end{array}$} & Frequent & 5 & Catastrophic & 5 & $\begin{array}{l}\text { Eksteme } \\
19,5-25\end{array}$ \\
\hline & Probable & 4 & Critical & 4 & $\begin{array}{c}\text { High } \\
12.5-19.4\end{array}$ \\
\hline & Occesional & 3 & Moderate & 3 & $\begin{array}{l}\text { Substansial } \\
9.5-12.4\end{array}$ \\
\hline & Remote & 2 & Minor & 2 & $\begin{array}{l}\text { Medium } \\
4.5-9.4\end{array}$ \\
\hline & Improbable & 1 & Negligible & 1 & Low 1 - 4.4 \\
\hline & \multicolumn{5}{|c|}{ Deskriptif Jawaban Responden } \\
\hline & \multicolumn{2}{|c|}{\begin{tabular}{l|l|l|} 
Banyak & Peluang \\
Responden & Risiko \\
\end{tabular}} & $\begin{array}{l}\text { Dampak } \\
\text { Risiko }\end{array}$ & $\begin{array}{l}\text { Risiko } \\
\text { (PXD) }\end{array}$ & \\
\hline & 1 & 2 & 2 & 4 & Low \\
\hline & 2 & 2 & 2 & 4 & Low \\
\hline & 3 & 2 & 2 & 4 & Low \\
\hline & 4 & 2 & 2 & 4 & Low \\
\hline & $f / n=\%$ & 8 & 8 & 16 & Low \\
\hline & & 2 & 2 & 4 & \\
\hline
\end{tabular}

Sumber : Diolah, 2017

I. Dampak:

a. Tim Pelaksanaan melakukan dispute data kepemilikan tanah yang ingin dibebaskan

b. Tim Pelaksanaan melakukan kesalahan pengukuran tanah milik warga yang dibutuhkan untuk pengadaaan lahan untuk kepentingan umum

2. Diagram Peluang Dampak

Berdasarkan hasil pegukuran pada tabel 4.23, dengan hasil peluang risiko sebesar 2 dan dampak risiko sebesar 2, maka nilai risiko ( $P X D)$ sebesar 4 dan nilai risk assessment matrix nya adalah Low dan dapat dijabarkan kedalam diagram peluang dampak sebagai berikut :

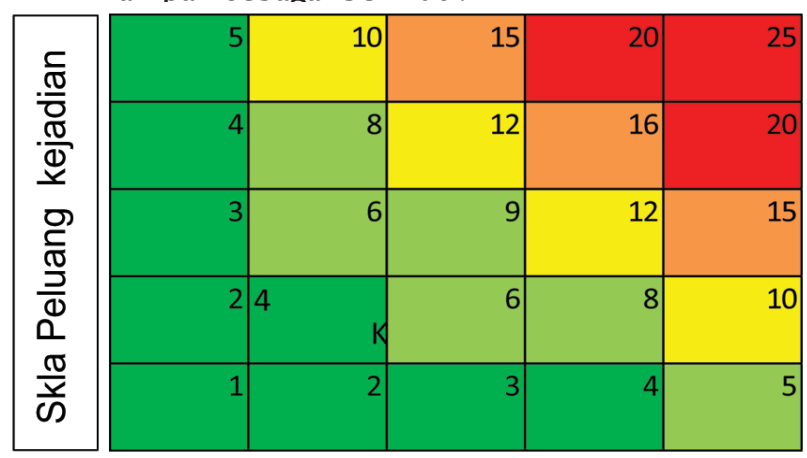

Skala dampak kejadian

Gambar 4.I5 Diagram Peluang Dampak Risiko Pada Inventarisasi Dan Identifikasi Identifikasi Risiko Muncul Gejolak Sosial 
Mitigasi risiko (mengecilkan peluang dan dampak risiko bagi sub tahapan Inventarisasi dan Identifikasi dari tahapan Pelaksanaan) :

I. Tim Pelaksanaan berkoordinasi dengan muspika selaku wakil pemerintah daerah terkecil seharusnya memiliki data kepemilikan tanah masyarakat setempat yang selalu terupdate, terupdate yang dimaksud adalah kepemilikan tanah warga benar secara hukum keabsahannya, dan apabila tanah tersebut telah diperjualbelikan muspika mengetahuinya dan memiliki copy berkas jual beli.

2. Melakukan sosialisasi dengan cara penyampaian dan bahasa yang mudah dimengerti kepada masyarakat setempat, jika perlu menggunakan bahasa daerah setempat dan dimediasi oleh muspika setempat serta orang yang dituakan oleh warga setempat.

Berdasarkan distribusi kuesioner penelitian yang dibagikan kepada empat (4 orang) responden dengan subfokus identifikasi risiko "Waktu pengerjaan tidak sesuai dengan tata waktu” pada sub tahapan Penilaian ganti Rugi dari tahapan Pelaksanaan, dan didapatkan hasil risikonya, sebagai berikut :

\section{I3 Pengukuran Risiko Pada Penilaian Ganti Rugi Identifikasi Risiko Waktu Pengerjaan Tidak Sesuai Dengan Tata Waktu}

\begin{tabular}{|c|c|c|c|c|c|}
\hline \multirow{2}{*}{$\begin{array}{l}\text { Identifikasi } \\
\text { Risiko }\end{array}$} & \multicolumn{2}{|c|}{ Peluang Risiko } & \multicolumn{2}{|c|}{ Dampak Risiko } & \multirow{2}{*}{$\begin{array}{c}\text { Risk } \\
\text { Assessment } \\
\text { Matrix }\end{array}$} \\
\hline & Verbal & $\begin{array}{l}\text { Num } \\
\text { erik }\end{array}$ & Verbal & $\begin{array}{c}\text { Num } \\
\text { erik }\end{array}$ & \\
\hline \multirow{13}{*}{$\begin{array}{l}\text { Waktu } \\
\text { pengerjaan } \\
\text { tidak } \\
\text { sesuai } \\
\text { dengan } \\
\text { tata } \\
\text { waktu }\end{array}$} & Frequent & 5 & Catastrophic & 5 & $\begin{array}{c}\text { Eksteme } \\
19,5-25\end{array}$ \\
\hline & Probable & 4 & Critical & 4 & $\begin{array}{c}\text { High } \\
12.5-19.4\end{array}$ \\
\hline & Occesional & 3 & Moderate & 3 & $\begin{array}{c}\text { Substansial } \\
9.5-12.4\end{array}$ \\
\hline & Remote & 2 & Minor & 2 & $\begin{array}{l}\text { Medium } \\
4.5-9.4\end{array}$ \\
\hline & Improbable & 1 & Negligible & 1 & Low 1 - 4.4 \\
\hline & \multicolumn{5}{|c|}{ Deskriptif Jawaban Responden } \\
\hline & $\begin{array}{l}\text { Banyak } \\
\text { Responden }\end{array}$ & $\begin{array}{l}\text { Peluang } \\
\text { Risiko }\end{array}$ & $\begin{array}{l}\text { Dampak } \\
\text { Risiko }\end{array}$ & $\begin{array}{l}\text { Risiko } \\
\text { (PXD) }\end{array}$ & \\
\hline & 1 & 5 & 2 & 10 & Substansial \\
\hline & 2 & 5 & 2 & 10 & Substansial \\
\hline & 3 & 5 & 2 & 10 & Substansial \\
\hline & 4 & 5 & 2 & 10 & Substansial \\
\hline & \multirow[t]{2}{*}{$f / n=\%$} & 20 & 8 & 40 & \multirow[t]{2}{*}{ Substansial } \\
\hline & & 5 & 2 & 10 & \\
\hline
\end{tabular}

Sumber : Diolah, 2017
I. Dampak:

a. Pemilik lahan tidak menghadiri kegiatan Konsultasi Publik dikarenakan tidak sampainya undangan, dan pemilik lahan tidak mengerti maksud dan tujuan yang diutarakan oleh tim persiapan.

2. Diagram Peluang Dampak

Berdasarkan hasil pegukuran pada tabel 4.24, dengan hasil peluang risiko sebesar 5 dan dampak risiko sebesar 2, maka nilai risiko (PXD) sebesar 10 dan nilai risk assessment matrix nya adalah Substansial dan dapat dijabarkan kedalam diagram peluang dampak sebagai berikut :

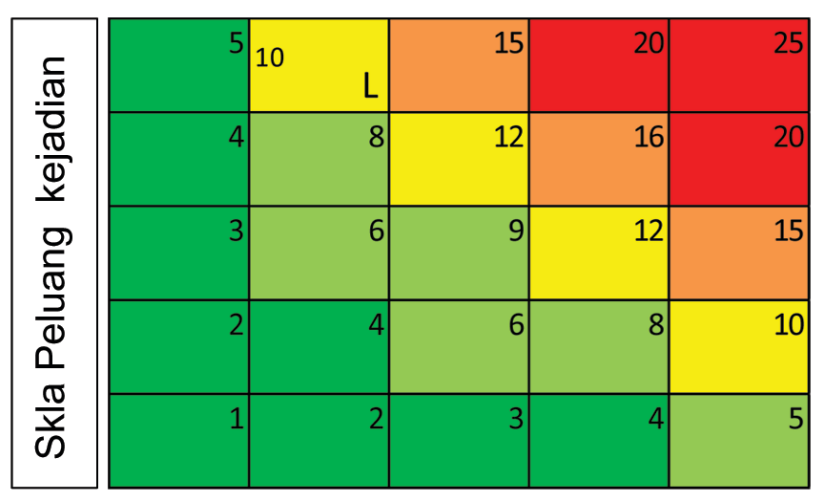

Skala dampak kejadian

Gambar 4.16 Diagram Peluang Dampak Risiko Pada Penilaian Ganti Rugi Identifikasi Risiko Waktu Pengerjaan Tidak Sesuai Dengan Tata Waktu

3. Mitigasi risiko (mengecilkan peluang dan dampak risiko bagi sub tahapan tahapan Penilaian ganti Rugi dari tahapan Pelaksanaan) :

Tim Persiapan berkoordinasi dengan muspika selaku wakil pemerintah daerah terkecil seharusnya memiliki data kepemilikan tanah masyarakat setempat yang selalu terupdate, terupdate yang dimaksud adalah kepemilikan tanah warga benar secara hukum keabsahannya, dan apabila tanah tersebut telah diperjualbelikan muspika mengetahuinya dan memiliki copy berkas jual beli.

Berdasarkan distribusi kuesioner penelitian yang dibagikan kepada empat (4 orang) responden dengan subfokus identifikasi risiko "Muncul gejolak sosial" pada sub tahapan Penilaian ganti Rugi dari tahapan Pelaksanaan, dan didapatkan hasil risikonya, sebagai berikut: 
Tabel 4. I4 Pengukuran Risiko Pada Penilaian Ganti Rugi Identifikasi Risiko Muncul Gejolak Sosial

\begin{tabular}{|c|c|c|c|c|c|}
\hline \multirow{2}{*}{$\begin{array}{l}\text { Identifikasi } \\
\text { Risiko }\end{array}$} & \multicolumn{2}{|c|}{ Peluang Risiko } & \multicolumn{2}{|c|}{ Dampak Risiko } & \multirow{2}{*}{$\begin{array}{c}\text { Risk } \\
\text { Assessment } \\
\text { Matrix }\end{array}$} \\
\hline & Verbal & $\begin{array}{l}\text { Num } \\
\text { erik }\end{array}$ & Verbal & $\begin{array}{c}\text { Num } \\
\text { erik }\end{array}$ & \\
\hline \multirow{13}{*}{$\begin{array}{l}\text { Muncul } \\
\text { gejolak } \\
\text { sosial }\end{array}$} & Frequent & 5 & Catastrophic & 5 & $\begin{array}{l}\text { Eksteme } \\
19,5-25\end{array}$ \\
\hline & Probable & 4 & Critical & 4 & $\begin{array}{c}\text { High } \\
12.5-19.4\end{array}$ \\
\hline & Occesional & 3 & Moderate & 3 & $\begin{array}{c}\text { Substansial } \\
9.5-12.4\end{array}$ \\
\hline & Remote & 2 & Minor & 2 & $\begin{array}{l}\text { Medium } \\
4.5-9.4\end{array}$ \\
\hline & Improbable & 1 & Negligible & 1 & Low 1 - 4.4 \\
\hline & \multicolumn{5}{|c|}{ Deskriptif Jawaban Responden } \\
\hline & $\begin{array}{l}\text { Banyak } \\
\text { Responden }\end{array}$ & $\begin{array}{l}\text { Peluang } \\
\text { Risiko }\end{array}$ & \begin{tabular}{|l|} 
Dampak \\
Risiko
\end{tabular} & \begin{tabular}{|l} 
Risiko \\
(PXD)
\end{tabular} & \\
\hline & 1 & 5 & 2 & 10 & Substansial \\
\hline & 2 & 4 & 4 & 16 & Substansial \\
\hline & 3 & 4 & 2 & 8 & Substansial \\
\hline & 4 & 5 & 2 & 10 & Substansial \\
\hline & \multirow{2}{*}{$f / n=\%$} & 18 & 10 & 44 & \multirow[t]{2}{*}{ Substansial } \\
\hline & & 4.5 & 2.5 & 11 & \\
\hline
\end{tabular}

Sumber : Diolah, 2017

I. Dampak:

a. Munculnya gugatan dari warga pemilik lahan yang keberatan dengan nilai ganti rugi/kompensasi

2. Diagram Peluang Dampak

Berdasarkan hasil pegukuran pada tabel 4.26, dengan hasil peluang risiko sebesar 2 dan dampak risiko sebesar 2, maka nilai risiko (PXD) sebesar II dan nilai risk assessment matrix nya adalah Substansial dan dapat dijabarkan kedalam diagram peluang dampak sebagai berikut :

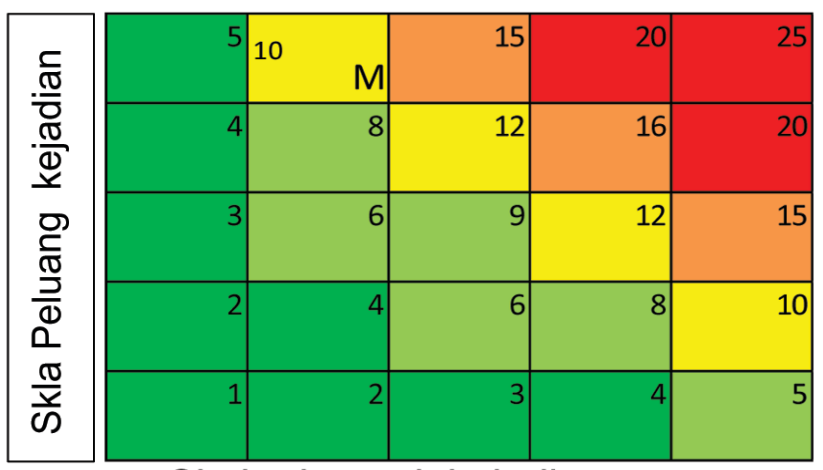

Skala dampak kejadian

Gambar 4. I7 Diagram Peluang Dampak Risiko Pada Penilaian Ganti Rugi Identifikasi Risiko Muncul Gejolak Sosial
3. Mitigasi risiko (mengecilkan peluang dan dampak risiko bagi sub tahapan Penilaian ganti Rugi dari tahapan Pelaksanaan) :

Tim Pelaksana berkoordinasi dengan muspika dan orang yang dituakan oleh warga setempat untuk memediasi kan dengan warga setempat bahwa, nilai ganti rugi yang ditawarkan merupakan penilaian oleh tim independent yang telah menilai objek tanah.

Berdasarkan distribusi kuesioner penelitian yang dibagikan kepada empat (4 orang) responden dengan subfokus identifikasi risiko "Waktu pengerjaan tidak sesuai dengan tata waktu" pada sub tahapan Musyawarah penetapan ganti rugi dari tahapan Pelaksanaan, dan didapatkan hasil risikonya, sebagai berikut :

Tabel 4. I5 Pengukuran Risiko Pada Musyawarah Penetapan Ganti Rugi Identifikasi Risiko Waktu Pengerjaan Tidak Sesuai Dengan Tata Waktu

\begin{tabular}{|c|c|c|c|c|c|}
\hline \multirow{2}{*}{$\begin{array}{l}\text { Identifikasi } \\
\text { Risiko }\end{array}$} & \multicolumn{2}{|c|}{ Peluang Risiko } & \multicolumn{2}{|c|}{ Dampak Risiko } & \multirow{2}{*}{$\begin{array}{c}\text { Risk } \\
\text { Assessment } \\
\text { Matrix }\end{array}$} \\
\hline & Verbal & $\begin{array}{l}\text { Num } \\
\text { erik }\end{array}$ & Verbal & $\begin{array}{c}\text { Num } \\
\text { erik }\end{array}$ & \\
\hline \multirow{13}{*}{$\begin{array}{l}\text { Waktu } \\
\text { pengerjaan } \\
\text { tidak } \\
\text { sesuai } \\
\text { dengan } \\
\text { tata } \\
\text { waktu }\end{array}$} & Frequent & 5 & Catastrophic & 5 & $\begin{array}{l}\text { Eksteme } \\
19,5-25\end{array}$ \\
\hline & Probable & 4 & Critical & 4 & $\begin{array}{c}\text { High } \\
12.5-19.4\end{array}$ \\
\hline & Occesional & 3 & Moderate & 3 & \begin{tabular}{|l} 
Substansial \\
$9.5-12.4$
\end{tabular} \\
\hline & Remote & 2 & Minor & 2 & $\begin{array}{l}\text { Medium } \\
4.5-9.4\end{array}$ \\
\hline & Improbable & 1 & Negligible & 1 & Low $1-4.4$ \\
\hline & \multicolumn{5}{|c|}{ Deskriptif Jawaban Responden } \\
\hline & \multicolumn{2}{|c|}{\begin{tabular}{l|l} 
Banyak & Peluang \\
Responden & Risiko
\end{tabular}} & \begin{tabular}{|l} 
Dampak \\
Risiko
\end{tabular} & $\begin{array}{l}\text { Risiko } \\
\text { (PXD) }\end{array}$ & \\
\hline & 1 & 4 & 2 & 8 & Medium \\
\hline & 2 & 5 & 4 & 10 & Substansial \\
\hline & 3 & 5 & 2 & 10 & Substansial \\
\hline & 4 & 5 & 2 & 10 & Substansial \\
\hline & \multirow[t]{2}{*}{$f / n=\%$} & 19 & 8 & 38 & \multirow[t]{2}{*}{ Substansial } \\
\hline & & 4.75 & 2 & 9.5 & \\
\hline
\end{tabular}

Sumber : Diolah, 2017

I. Dampak:

a. Tidak bertemunya kata sepakat antara warga dengan tim pelaksanaan

b. pemilik lahan tidak menghadiri kegiatan Musyawarah Penetapan Ganti Rugi, dikarenakan tidak menerima undangan dan tidak mengertinya maksud dan tujuan dari Musyawarah Penetapan Ganti Rugi 
2. Diagram Peluang Dampak

Berdasarkan hasil pegukuran pada tabel 4.28, dengan hasil peluang risiko sebesar 4.75 dan dampak risiko sebesar 2, maka nilai risiko ( $\mathrm{P} X$ D) sebesar 9.5 dan nilai risk assessment matrix nya adalah Substansial dan dapat dijabarkan kedalam diagram peluang dampak sebagai berikut:

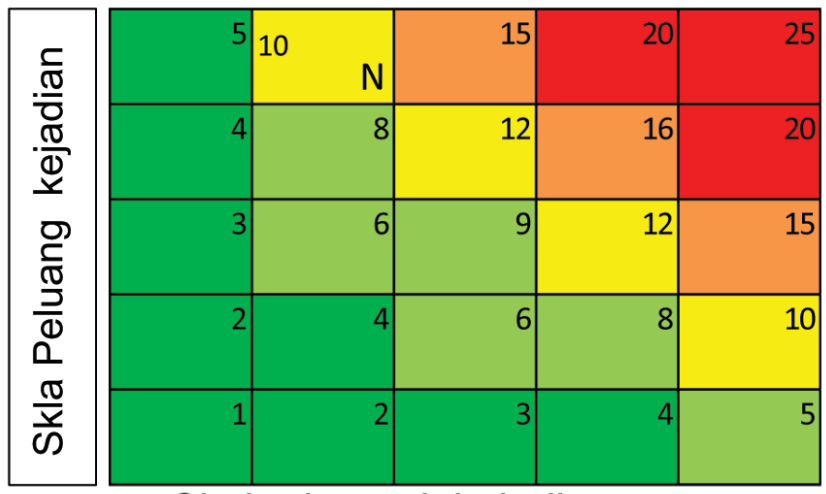

Skala dampak kejadian

Gambar 4.18 Diagram Peluang Dampak Risiko Pada Musyawarah Penetapan Ganti Rugi Identifikasi Risiko Waktu Pengerjaan Tidak Sesuai Dengan Tata Waktu

3. Mitigasi risiko (mengecilkan peluang dan dampak risiko bagi sub tahapan tahapan Musyawarah penetapan ganti rugi dari tahapan Pelaksanaan):

I. Sosialisasi kan maksud dan tujuan dari Musyawarah Penetapan Ganti Rugi menggunakan bahasa yang mudah dimengerti kepada masyarakan setempat, jika perlu menggunakan bahasa daerah setempat dan dimediasi oleh muspika serta orang yang dituakan oleh warga setempat.

2. Tim Pelaksana berkoordinasi dengan muspika dan orang yang dituakan oleh warga setempat untuk memediasi kan dengan warga setempat bahwa, bentuk ganti rugi yang ditawarkan merupakan penilaian oleh tim independent yang telah menilai objek tanah.

Berdasarkan distribusi kuesioner penelitian yang dibagikan kepada empat (4 orang) responden dengan subfokus identifikasi risiko "Muncul gejolak sosial" pada sub tahapan Musyawarah penetapan ganti rugi dari tahapan Pelaksanaan, dan didapatkan hasil risikonya, sebagai berikut:

\section{Tabel 4. I 6 Pengukuran Risiko Pada Musyawarah Penetapan Ganti Rugi Identifikasi Risiko Muncul Gejolak Sosial}

\begin{tabular}{|c|c|c|c|c|c|}
\hline \multirow{2}{*}{$\begin{array}{l}\text { Identifikasi } \\
\text { Risiko }\end{array}$} & \multicolumn{2}{|c|}{ Peluang Risiko } & \multicolumn{2}{|c|}{ Dampak Risiko } & \multirow{2}{*}{$\begin{array}{c}\text { Risk } \\
\text { Assessment } \\
\text { Matrix }\end{array}$} \\
\hline & Verbal & $\begin{array}{l}\text { Num } \\
\text { erik }\end{array}$ & Verbal & $\begin{array}{c}\text { Num } \\
\text { erik }\end{array}$ & \\
\hline \multirow{13}{*}{$\begin{array}{l}\text { Muncul } \\
\text { gejolak } \\
\text { sosial }\end{array}$} & Frequent & 5 & Catastrophic & 5 & $\begin{array}{l}\text { Eksteme } \\
19,5-25\end{array}$ \\
\hline & Probable & 4 & Critical & 4 & $\begin{array}{c}\text { High } \\
12.5-19.4\end{array}$ \\
\hline & Occesional & 3 & Moderate & 3 & $\begin{array}{c}\text { Substansial } \\
9.5-12.4\end{array}$ \\
\hline & Remote & 2 & Minor & 2 & $\begin{array}{l}\text { Medium } \\
4.5-9.4\end{array}$ \\
\hline & Improbable & 1 & Negligible & 1 & Low 1 - 4.4 \\
\hline & \multicolumn{5}{|c|}{ Deskriptif Jawaban Responden } \\
\hline & $\begin{array}{l}\text { Banyak } \\
\text { Responden }\end{array}$ & \begin{tabular}{|l} 
Peluang \\
Risiko
\end{tabular} & $\begin{array}{l}\text { Dampak } \\
\text { Risiko }\end{array}$ & $\begin{array}{l}\text { Risiko } \\
\text { (PXD) }\end{array}$ & \\
\hline & 1 & 5 & 2 & 10 & Substansial \\
\hline & 2 & 5 & 2 & 10 & High \\
\hline & 3 & 5 & 2 & 10 & Medium \\
\hline & 4 & 5 & 3 & 15 & Substansial \\
\hline & \multirow[t]{2}{*}{$f / n=\%$} & 20 & 9 & 45 & \multirow[t]{2}{*}{ Substansial } \\
\hline & & 5 & 2.25 & 11.25 & \\
\hline
\end{tabular}

Sumber : Diolah, 2017

I. Dampak:

a. Munculnya gugatan dari warga pemilik lahan yang keberatan dengan bentuk ganti rugi/kompensasi mengakibatkan tuntutan/ demonstrasi hingga penutupan jalan.

b. pemilik lahan tidak menghadiri kegiatan Musyawarah Penetapan Ganti Rugi, dikarenakan tidak menerima undangan dan tidak mengertinya maksud dan tujuan dari Musyawarah Penetapan Ganti Rugi.

\section{Diagram Peluang Dampak}

Berdasarkan hasil pegukuran pada tabel 4.30, dengan hasil peluang risiko sebesar 5 dan dampak risiko sebesar 2.25 , maka nilai risiko $(P \times D)$ sebesar II.25 dan nilai risk assessment matrix nya adalah Substansial dan dapat dijabarkan kedalam diagram peluang dampak sebagai berikut : 


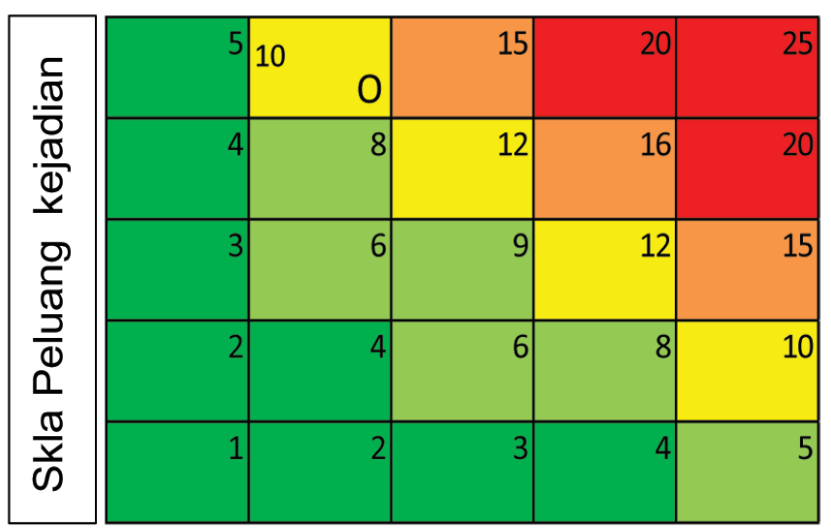

Skala dampak kejadian

Gambar 4.19 Diagram Peluang Dampak Risiko Pada Musyawarah Penetapan Ganti Rugi Identifikasi Risiko Muncul Gejolak Sosial

3. Mitigasi risiko (mengecilkan peluang dan dampak risiko bagi sub tahapan Musyawarah penetapan ganti rugi dari tahapan Pelaksanaan) :

I. Sosialisasi kan maksud dan tujuan dari Musyawarah Penetapan Ganti Rugi menggunakan bahasa yang mudah dimengerti kepada masyarakan setempat, jika perlu menggunakan bahasa daerah setempat dan dimediasi oleh muspika serta orang yang dituakan oleh warga setempat.

2. Tim Pelaksana berkoordinasi dengan muspika dan orang yang dituakan oleh warga setempat untuk memediasi kan dengan warga setempat bahwa, bentuk ganti rugi yang ditawarkan merupakan penilaian oleh tim independent yang telah menilai objek tanah.

Berdasarkan distribusi kuesioner penelitian yang dibagikan kepada empat (4 orang) responden dengan subfokus identifikasi risiko "Waktu pengerjaan tidak sesuai dengan tata waktu" pada sub tahapan Pemberian ganti rugi dari tahapan Pelaksanaan, dan didapatkan hasil risikonya, sebagai berikut :

Tabel 4.I7 Pengukuran Risiko Pada Pemberian Ganti Rugi Identifikasi Risiko Waktu Pengerjaan Tidak Sesuai Dengan Tata Waktu

\begin{tabular}{|c|c|c|c|c|c|}
\hline \multirow{2}{*}{$\begin{array}{l}\text { Identifikasi } \\
\text { Risiko }\end{array}$} & \multicolumn{2}{|c|}{ Peluang Risiko } & \multicolumn{2}{|c|}{ Dampak Risiko } & \multirow{2}{*}{$\begin{array}{c}\text { Risk } \\
\text { Assessment } \\
\text { Matrix }\end{array}$} \\
\hline & Verbal & $\begin{array}{l}\text { Num } \\
\text { erik }\end{array}$ & Verbal & $\begin{array}{c}\text { Num } \\
\text { erik }\end{array}$ & \\
\hline \multirow{13}{*}{$\begin{array}{l}\text { Waktu } \\
\text { pengerjaan } \\
\text { tidak } \\
\text { sesuai } \\
\text { dengan } \\
\text { tata } \\
\text { waktu }\end{array}$} & Frequent & 5 & Catastrophic & 5 & $\begin{array}{c}\text { Eksteme } \\
19,5-25\end{array}$ \\
\hline & Probable & 4 & Critical & 4 & $\begin{array}{c}\text { High } \\
12.5-19.4\end{array}$ \\
\hline & Occesional & 3 & Moderate & 3 & \begin{tabular}{|c|} 
Substansial \\
$9.5-12.4$
\end{tabular} \\
\hline & Remote & 2 & Minor & 2 & $\begin{array}{l}\text { Medium } \\
4.5-9.4\end{array}$ \\
\hline & Improbable & 1 & Negligible & 1 & Low $1-4.4$ \\
\hline & \multicolumn{5}{|c|}{ Deskriptif Jawaban Responden } \\
\hline & $\begin{array}{l}\text { Banyak } \\
\text { Responden }\end{array}$ & $\begin{array}{l}\text { Peluang } \\
\text { Risiko }\end{array}$ & $\begin{array}{l}\text { Dampak } \\
\text { Risiko }\end{array}$ & $\begin{array}{l}\text { Risiko } \\
\text { (PXD) }\end{array}$ & \\
\hline & 1 & 5 & 2 & 10 & Substansial \\
\hline & 2 & 5 & 2 & 10 & Substansial \\
\hline & 3 & 5 & 2 & 10 & Substansial \\
\hline & 4 & 5 & 2 & 10 & Substansial \\
\hline & \multirow[t]{2}{*}{$f / n=\%$} & 20 & 8 & 40 & \multirow[t]{2}{*}{ Substansial } \\
\hline & & 5 & 2 & 10 & \\
\hline
\end{tabular}

Sumber : Diolah, 2017

I. Dampak:

a. Tim Pelaksanaan melakukan dispute data kepemilikan tanah yang ingin dibebaskan saat proses pembayaran berlangsung.

2. Diagram Peluang Dampak

Berdasarkan hasil pegukuran pada tabel 4.32, dengan hasil peluang risiko sebesar 5 dan dampak risiko sebesar 2, maka nilai risiko (PXD) sebesar 10 dan nilai risk assessment matrix nya adalah Substansial dan dapat dijabarkan kedalam diagram peluang dampak sebagai berikut :

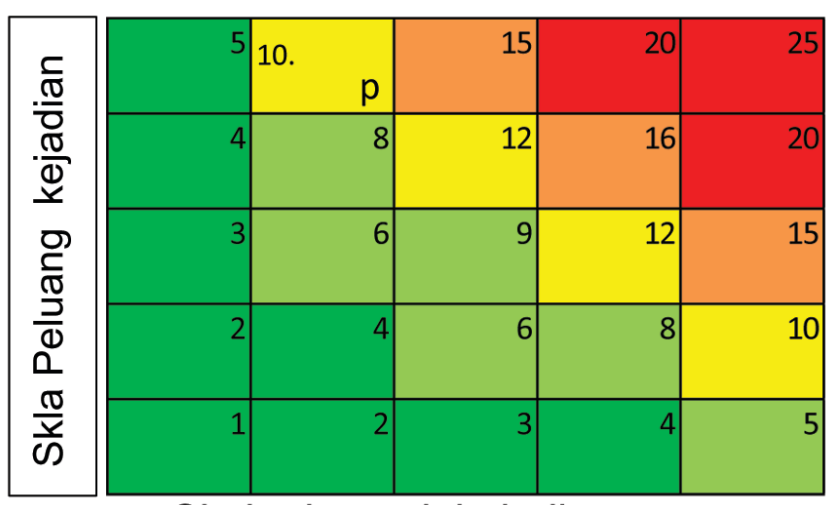

Skala dampak kejadian

Gambar 4.20 Diagram Peluang Dampak Risiko Pada Pemberian Ganti Rugi Identifikasi Risiko Waktu Pengerjaan Tidak Sesuai Dengan Tata Waktu 
3. Mitigasi risiko (mengecilkan peluang dan dampak risiko bagi sub tahapan tahapan Pemberian ganti rugi dari tahapan Pelaksanaan) :

I. Proses Inventarisasi \& Identifikasi dilakukan dengan semaksimal mungkin untuk mengidentifikasi kepemilikan lahan.

2. Tim Persiapan berkoordinasi dengan muspika selaku wakil pemerintah daerah terkecil seharusnya memiliki data kepemilikan tanah masyarakat setempat yang selalu terupdate, terupdate yang dimaksud adalah kepemilikan tanah warga benar secara hukum keabsahannya, dan apabila tanah tersebut telah diperjualbelikan muspika mengetahuinya dan memiliki copy berkas jual beli.

Berdasarkan distribusi kuesioner penelitian yang dibagikan kepada empat (4 orang) responden dengan subfokus identifikasi risiko "Muncul gejolak sosial" pada sub tahapan Pemberian ganti rugi dari tahapan Pelaksanaan, dan didapatkan hasil risikonya, sebagai berikut:

Tabel 4. I 8 Pengukuran Risiko Pada Pemberian Ganti Rugi Identifikasi Risiko Muncul Gejolak Sosial

\begin{tabular}{|c|c|c|c|c|c|}
\hline \multirow{2}{*}{$\begin{array}{l}\text { Identifikasi } \\
\text { Risiko }\end{array}$} & \multicolumn{2}{|c|}{ Peluang Risiko } & \multicolumn{2}{|c|}{ Dampak Risiko } & \multirow{2}{*}{$\begin{array}{c}\text { Risk } \\
\text { Assessment } \\
\text { Matrix }\end{array}$} \\
\hline & Verbal & $\begin{array}{l}\text { Num } \\
\text { erik }\end{array}$ & Verbal & $\begin{array}{c}\text { Num } \\
\text { erik }\end{array}$ & \\
\hline \multirow{13}{*}{$\begin{array}{l}\text { Muncul } \\
\text { gejolak } \\
\text { sosial }\end{array}$} & Frequent & 5 & Catastrophic & 5 & $\begin{array}{l}\text { Eksteme } \\
19,5 \text { - } 25\end{array}$ \\
\hline & Probable & 4 & Critical & 4 & $\begin{array}{c}\text { High } \\
12.5-19.4\end{array}$ \\
\hline & Occesional & 3 & Moderate & 3 & $\begin{array}{c}\text { Substansial } \\
9.5-12.4\end{array}$ \\
\hline & Remote & 2 & Minor & 2 & $\begin{array}{l}\text { Medium } \\
4.5-9.4\end{array}$ \\
\hline & Improbable & 1 & Negligible & 1 & Low $1-4.4$ \\
\hline & \multicolumn{5}{|c|}{ Deskriptif Jawaban Responden } \\
\hline & $\begin{array}{l}\text { Banyak } \\
\text { Responden }\end{array}$ & $\begin{array}{l}\text { Peluang } \\
\text { Risiko }\end{array}$ & $\begin{array}{l}\text { Dampak } \\
\text { Risiko }\end{array}$ & $\begin{array}{l}\text { Risiko } \\
\text { (PXD) }\end{array}$ & \\
\hline & 1 & 5 & 2 & 10 & Substansial \\
\hline & 2 & 5 & 2 & 10 & Substansial \\
\hline & 3 & 4 & 2 & 8 & Substansial \\
\hline & 4 & 5 & 2 & 10 & Substansial \\
\hline & \multirow[t]{2}{*}{$f / n=\%$} & 19 & 8 & 38 & \multirow[t]{2}{*}{ Substansial } \\
\hline & & 4.75 & 2 & 9.5 & \\
\hline
\end{tabular}

Sumber : Diolah, 2017

I. Dampak:

a. Tim Pelaksanaan melakukan dispute data kepemilikan tanah yang ingin dibebaskan saat proses pembayaran berlangsung.

2. Diagram Peluang Dampak

Berdasarkan hasil pegukuran pada tabel 4.34, dengan hasil peluang risiko sebesar 4.75 dan dampak risiko sebesar 1.75, maka nilai risiko ( $P$ $X \mathrm{D})$ sebesar 9.5 dan nilai risk assessment matrix nya adalah Substansial dan dapat dijabarkan kedalam diagram peluang dampak sebagai berikut:

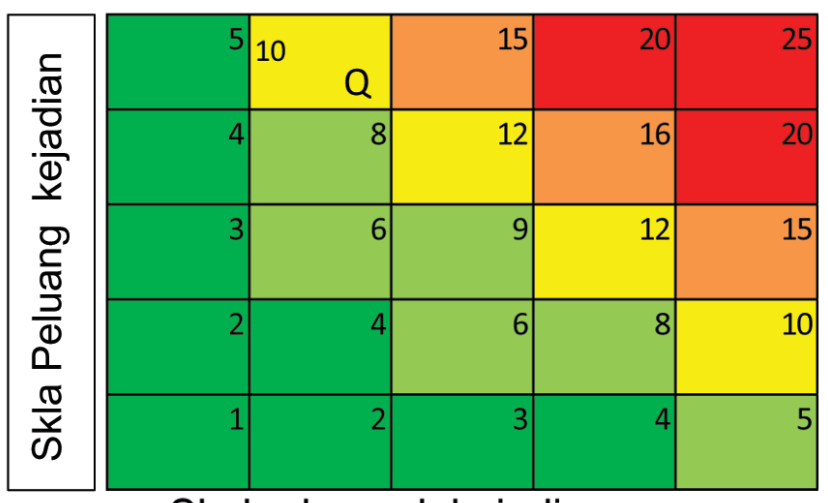

Skala dampak kejadian

Gambar 4.2I Diagram Peluang Dampak Risiko Pada Tahapan Pemberian Ganti Rugi Identifikasi Risiko Muncul Gejolak Sosial

3. Mitigasi risiko (mengecilkan peluang dan dampak risiko bagi sub tahapan Pemberian ganti rugi dari tahapan Pelaksanaan) :

Sosialisasi menggunakan bahasa yang mudah dimengerti kepada masyarakan setempat, jika perlu menggunakan bahasa daerah setempat dan dimediasi oleh muspika serta orang yang dituakan oleh warga setempat.

Berdasarkan distribusi kuesioner penelitian yang dibagikan kepada empat (4 orang) responden dengan subfokus identifikasi risiko "Waktu pengerjaan tidak sesuai dengan tata waktu" pada sub tahapan Pelepasan dan penghapusan hak atas tanah dari tahapan Pelaksanaan, dan didapatkan hasil risikonya, sebagai berikut :

Tabel 4. 19 Pengukuran Risiko Pada Pelepasan Dan Penghapusan Hak Atas Tanah Identifikasi Risiko Waktu Pengerjaan Tidak Sesuai Dengan Tata Waktu 


\begin{tabular}{|c|c|c|c|c|c|}
\hline \multirow{2}{*}{$\begin{array}{l}\text { Identifikasi } \\
\text { Risiko }\end{array}$} & \multicolumn{2}{|c|}{ Peluang Risiko } & \multicolumn{2}{|c|}{ Dampak Risiko } & \multirow{2}{*}{$\begin{array}{c}\text { Risk } \\
\text { Assessment } \\
\text { Matrix }\end{array}$} \\
\hline & Verbal & $\begin{array}{l}\text { Num } \\
\text { erik }\end{array}$ & Verbal & $\begin{array}{c}\text { Num } \\
\text { erik }\end{array}$ & \\
\hline \multirow{13}{*}{$\begin{array}{l}\text { Waktu } \\
\text { pengerjaan } \\
\text { tidak } \\
\text { sesuai } \\
\text { dengan } \\
\text { tata } \\
\text { waktu }\end{array}$} & Frequent & 5 & Catastrophic & 5 & $\begin{array}{l}\text { Eksteme } \\
19,5-25\end{array}$ \\
\hline & Probable & 4 & Critical & 4 & $\begin{array}{c}\text { High } \\
12.5-19.4\end{array}$ \\
\hline & Occesional & 3 & Moderate & 3 & $\begin{array}{c}\text { Substansial } \\
9.5-12.4\end{array}$ \\
\hline & Remote & 2 & Minor & 2 & $\begin{array}{l}\text { Medium } \\
4.5-9.4\end{array}$ \\
\hline & Improbable & 1 & Negligible & 1 & Low $1-4.4$ \\
\hline & \multicolumn{5}{|c|}{ Deskriptif Jawaban Responden } \\
\hline & $\begin{array}{l}\text { Banyak } \\
\text { Responden }\end{array}$ & $\begin{array}{l}\text { Peluang } \\
\text { Risiko }\end{array}$ & \begin{tabular}{|l|} 
Dampak \\
Risiko
\end{tabular} & $\begin{array}{l}\text { Risiko } \\
\text { (PXD) }\end{array}$ & \\
\hline & 1 & 5 & 2 & 10 & Substansial \\
\hline & 2 & 4 & 3 & 12 & Substansial \\
\hline & 3 & 4 & 2 & 8 & Substansial \\
\hline & 4 & 5 & 2 & 10 & Substansial \\
\hline & \multirow[t]{2}{*}{$f / n=\%$} & 19 & 9 & 40 & \multirow[t]{2}{*}{ Substansial } \\
\hline & & 4.5 & 2.25 & 10 & \\
\hline
\end{tabular}

Sumber : Diolah, 2017

I. Dampak:

a. Undangan kegiatan Pelepasan dan penghapusan hak atas tanah dari Tim Pelaksanaan tidak sampai kepada pemilik lahan,

2. Diagram Peluang Dampak

Berdasarkan hasil pegukuran pada tabel 4.36, dengan hasil peluang risiko sebesar 4.75 dan dampak risiko sebesar I.5, maka nilai risiko (P X D) sebesar 10.5 dan nilai risk assessment matrix nya adalah Substansial dan dapat dijabarkan kedalam diagram peluang dampak sebagai berikut:

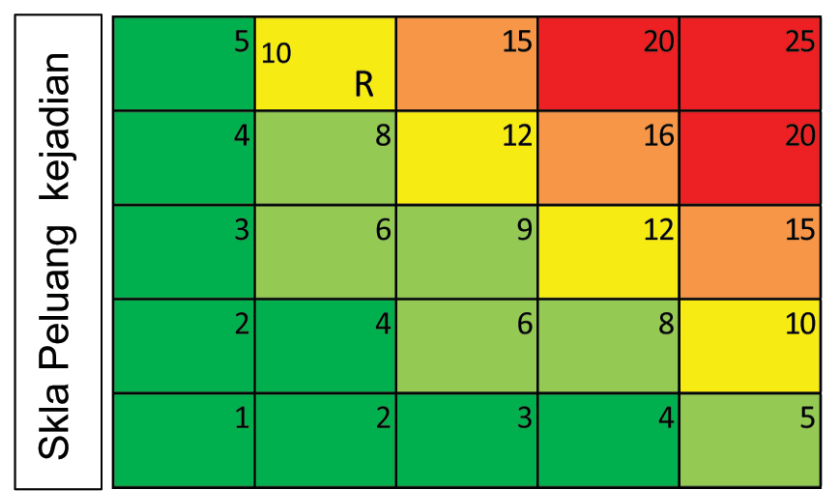

Skala dampak kejadian

Gambar 4.22 Diagram Peluang Dampak Risiko Pada Pelepasan Dan Penghapusan Hak Atas Tanah Identifikasi Risiko Waktu Pengerjaan Tidak Sesuai Dengan Tata Waktu
3. Mitigasi risiko (mengecilkan peluang dan dampak risiko bagi sub tahapan tahapan Pelepasan dan penghapusan hak atas tanah dari tahapan Pelaksanaan): Tim Pelaksana berkoordinasi dengan muspika dan orang yang dituakan oleh warga setempat untuk memastikan undangan untuk hadir dalam kegiatan tersebut.

\subsection{Analisis Identifikasi Pengukuran Risiko Penyerahan Hasil}

Berdasarkan distribusi kuesioner penelitian yang dibagikan kepada empat (4 orang) responden dengan subfokus identifikasi risiko "Waktu pengerjaan tidak sesuai dengan tata waktu" pada sub tahapan Penyerahan hasil dari tahapan Penyerahan hasil, dan didapatkan hasil risikonya, sebagai berikut :

Tabel 4.20 Pengukuran Risiko Pada Penyerahan Hasil Identifikasi Risiko Waktu Pengerjaan Tidak Sesuai Dengan Tata Waktu

\begin{tabular}{|c|c|c|c|c|c|}
\hline \multirow{2}{*}{$\begin{array}{l}\text { Identifikasi } \\
\text { Risiko }\end{array}$} & \multicolumn{2}{|c|}{ Peluang Risiko } & \multicolumn{2}{|c|}{ Dampak Risiko } & \multirow{2}{*}{$\begin{array}{c}\text { Risk } \\
\text { Assessment } \\
\text { Matrix }\end{array}$} \\
\hline & Verbal & $\begin{array}{l}\text { Num } \\
\text { erik }\end{array}$ & Verbal & $\begin{array}{c}\text { Num } \\
\text { erik }\end{array}$ & \\
\hline \multirow{13}{*}{$\begin{array}{l}\text { Waktu } \\
\text { pengerjaan } \\
\text { tidak } \\
\text { sesuai } \\
\text { dengan } \\
\text { tata } \\
\text { waktu }\end{array}$} & Frequent & 5 & Catastrophic & 5 & $\begin{array}{c}\text { Eksteme } \\
19,5-25\end{array}$ \\
\hline & Probable & 4 & Critical & 4 & $\begin{array}{c}\text { High } \\
12.5-19.4\end{array}$ \\
\hline & Occesional & 3 & Moderate & 3 & $\begin{array}{c}\text { Substansial } \\
9.5-12.4\end{array}$ \\
\hline & Remote & 2 & Minor & 2 & $\begin{array}{l}\text { Medium } \\
4.5-9.4\end{array}$ \\
\hline & Improbable & 1 & Negligible & 1 & Low $1-4.4$ \\
\hline & \multicolumn{5}{|c|}{ Deskriptif Jawaban Responden } \\
\hline & $\begin{array}{l}\text { Banyak } \\
\text { Responden }\end{array}$ & $\begin{array}{l}\text { Peluang } \\
\text { Risiko }\end{array}$ & \begin{tabular}{|l} 
Dampak \\
Risiko
\end{tabular} & $\begin{array}{l}\text { Risiko } \\
\text { (PXD) }\end{array}$ & \\
\hline & 1 & 5 & 2 & 10 & Substansial \\
\hline & 2 & 5 & 2 & 10 & Substansial \\
\hline & 3 & 5 & 2 & 10 & Substansial \\
\hline & 4 & 5 & 2 & 10 & Substansial \\
\hline & \multirow[t]{2}{*}{$f / n=\%$} & 20 & 8 & 40 & \multirow[t]{2}{*}{ Substansial } \\
\hline & & 5 & 2 & 10 & \\
\hline
\end{tabular}

Sumber : Diolah, 2017

I. Dampak:

I. Tim Pelaksanaan melakukan keterlambatan serah terima dokumen kepada instansi yang membutuhkan tanah. 
2. Diagram Peluang Dampak

Berdasarkan hasil pegukuran pada tabel 4.38, dengan hasil peluang risiko sebesar 5 dan dampak risiko sebesar 2, maka nilai risiko (PXD) sebesar 10 dan nilai risk assessment matrix nya adalah Substansial dan dapat dijabarkan kedalam diagram peluang dampak sebagai berikut :

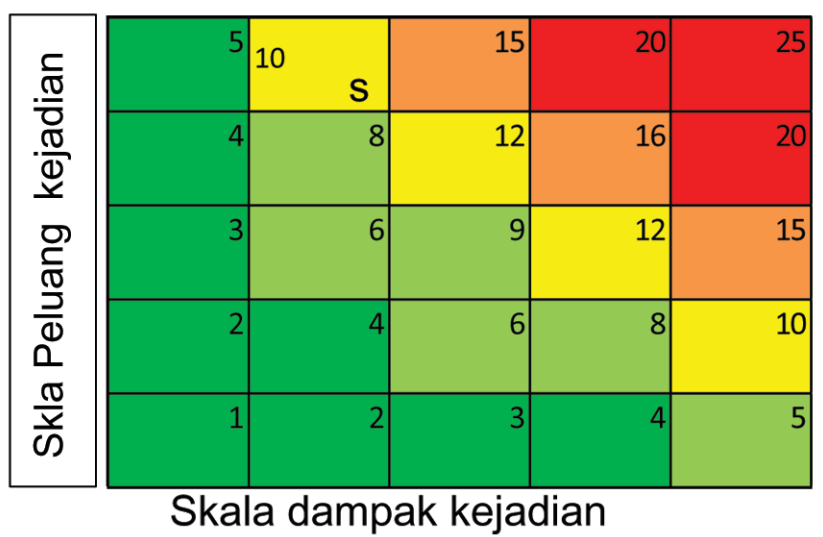

Gambar 4.22 Diagram Peluang Dampak Risiko Pada Pelepasan Dan Penghapusan Hak Atas Tanah Identifikasi Risiko Waktu Pengerjaan Tidak Sesuai Dengan Tata"Waktu

3. Mitigasi risiko (mengecilkan peluang dan dampak risiko bagi sub tahapan tahapan Penyerahan hasil dari tahapan Penyerahan hasil) :

Berkoordinasi dengan tim pelaksanaan PIC (BPN) untuk menanyakan update proses administrasi setiap harinya. Dan berkoordinasi dengan tim pengatur jadwal Pejabat Pemeritah Daerah untuk selalu mengingatkan penyelesaian proses adminstrasi harus segera diselesaikan oleh Pejabat Pemeritah Daerah

\subsection{Kebijakan Manajemen Risiko}

I. Kebijakan manajemen risiko untuk tahapan pengajuan Dokumen

I. Risiko Operasional :

Dispute data pengajuan tanah untuk kepentingan umum dengan kondisi di lapangan yang terlalu menyimpang.

2. Jenis kejadian yang tidak diinginkan:

Instansi yang membutuhkan lahan melakukan dispute data pengajuan tanah untuk kepentingan umum dengankondisi dilapangan yang terlalu menyimpang

3. Peluang kejadian:

a. Tujuh kejadian dari 8 pengajuan pengadaan tanah untuk kegiatan eksplorasi dan ekploitasi.

b. Lima dari skala lima (5).

4. Dampak potensial bagi Pengadaan Tanah Untuk Kepentingan Umum: Dilakukan revisi terhadap data pengajuan atau kondisi terparah adalah pengajuan tanah untuk kepentingan umum tidak dapat diproses oleh pemerintah daerah

5. Kebijakan manajemen risiko:

Survey pendahuluan ke lokasi yang dibutuhkan untuk mengumpulkan seluruh data-data yang dibutuhkan sedetail mungkin sehingga dispute data dapat di minimalisir semaksimal mungkin.

2. Kebijakan manajemen risiko untuk tahapan pemberitahuan rencana pembangunan

\section{Risiko Operasional:}

Ketidakmengertian maksud dan tujuan dari Pemberitahuan Rencana Pembangunan pengadaan lahan untuk kepentingan umum

2. Jenis kejadian yang tidak diinginkan:

Tim Persiapan melakukan sosialisasi (Pemberitahuan Rencana Pembangunan) yang susah dimengerti maksud dan tujuannya oleh Pemilk lahan.

3. Peluang kejadian:

a. Enam kejadian dari 8 pengajuan pengadaan tanah untuk kegiatan eksplorasi dan ekploitasi.

b. Empat dari skala lima (5).

I. Dampak potensial bagi Pengadaan Tanah Untuk Kepentingan Umum: Dilakukan kembali pemberitahuan rencana pembangunan yang mengakibatkan proses pengadaan lahan tidak sesuai dengan tata waktu yang sudah di tentukan, dan pembengkakan anggaran operasional dikarenakan pengulangan tahapan pemberitahuan rencana pembangunan

2. Kebijakan manajemen risiko:

Melakukan sosialisasi dengan cara penyampaian dan bahasa yang mudah dimengerti kepada masyarakat setempat, jika perlu menggunakan bahasa daerah setempat. 
3. Kebijakan manajemen risiko untuk tahapan Pemberitahuan rencana pembangunan

I. Risiko Operasional:

Tidak terinformasikannya pemilik lahan tentang Pemberitahuan Rencana Pembangunan dan tidak mengertinya pemilik lahan maksud dan tujuan dari pengadaan lahan untuk kepentingan umum.

2. Jenis kejadian yang tidak diinginkan:

a. Pemilik lahan tidak terinformasikan tentang pemberitahuan rencana pembangunan

b. Pemilik lahan tidak mengerti akan maksud dan tujuan penjelasan/sosialisasi dari pemberitahuan rencana pembangunan oleh tim persiapan

I) Peluang kejadian:

a) Tujuh kejadian dari 8 pengajuan pengadaan tanah untuk kegiatan eksplorasi dan ekploitasi.

b) Lima dari skala lima (5).

2) Dampak potensial bagi Pengadaan Tanah Untuk Kepentingan Umum: Pemilik lahan menolak akan rencana pembangunan dan mempertahankan haknya (tidak ingin tanahnya dibebaskan)

3) Kebijakan manajemen risiko:

Melakukan sosialisasi dengan cara penyampaian dan bahasa yang mudah dimengerti kepada masyarakat setempat, jika perlu menggunakan bahasa daerah setempat.

a. Melakukan sosialisasi dengan cara penyampaian dan bahasa yang mudah dimengerti kepada masyarakat setempat, jika perlu menggunakan bahasa daerah setempat.

b. Pemberitahuan Rencana Pembangunan dimediasi oleh muspika Setempat dan orang yang dituakan oleh warga setempat untuk meminimalisir konflik yang terjadi saat Pemberitahuan Rencana Pembanguan Berlangsung

3. Kebijakan manajemen risiko untuk tahapan Pendataan Awal

I) Risiko Operasional:

Dispute data kepemilikan tanah yang ingin dibebaskan

2) Jenis kejadian yang tidak diinginkan: Tim Persiapan melakukan sosialisasi (Pemberita- huan Rencana Pembangunan) yang susah dimengerti maksud dan tujuannya oleh Pemilk lahan.

a. Tim Persiapan melakukan dispute data kepemilikan tanah yang ingin dibebaskan

b. Pemilik lahan tidak mengerti akan maksud dan tujuan penjelasan/sosialisasi dari pemberitahuan rencana pembangunan oleh tim persiapan

3) Peluang kejadian:

a. Lima kejadian dari 8 pengajuan pengadaan tanah untuk kegiatan eksplorasi dan ekploitasi.

b. Empat dari skala lima (5).

4) Dampak potensial bagi Pengadaan Tanah Untuk Kepentingan Umum: Pemilik lahan menolak akan rencana pembangunan dan mempertahankan haknya (tidak ingin tanahnya dibebaskan)

5) Kebijakan manajemen risiko:

Melakukan sosialisasi dengan cara penyampaian dan bahasa yang mudah dimengerti kepada masyarakat setempat, jika perlu menggunakan bahasa daerah setempat.

a. Dengan cara penyampaian dan bahasa yang mudah dimengerti kepada masyarakat setempat, jika perlu menggunakan bahasa daerah setempat.

b. Pemberitahuan Rencana Pembangunan dimediasi oleh muspika Setempat dan orang yang dituakan oleh warga setempat untuk meminimalisir konflik yang terjadi saat Pemberitahuan Rencana Pembanguan Berlangsung

4. Kebijakan manajemen risiko untuk tahapan Pendataan Awal

I) Risiko Operasional:

Dispute data kepemilikan tanah yang ingin dibebaskan

2) Jenis kejadian yang tidak diinginkan:

Tim Persiapan melakukan dispute data kepemilikan tanah yang ingin dibebaskan

3) Peluang kejadian:

a. Tujuh kejadian dari 8 pengajuan pengadaan tanah untuk kegiatan eksplorasi dan ekploitasi.

b. Lima dari skala lima (5).

4) Dampak potensial bagi Pengadaan Tanah Untuk Kepentingan Umum: Dilakukan pendataan awal ulang yang mengakibatkan proses 
pengadaan lahan tidak sesuai dengan tata waktu yang sudah ditentukan dan pembengkakan anggaran operasional

5) Kebijakan manajemen risiko:

Tim Persiapan berkoordinasi dengan muspika selaku wakil pemerintah daerah terkecil seharusnya memiliki data kepemilikan tanah masyarakat setempat yang selalu terupdate, terupdate yang dimaksud adalah kepemilikan tanah warga benar secara hukum keabsahannya, dan apabila tanah tersebut telah diperjualbelikan muspika mengetahuinya dan memiliki copy berkas jual beli

5. Kebijakan manajemen risiko untuk tahapan Konsultasi Publik

I) Risiko Operasional:

Dispute data kepemilikan tanah yang ingin dibebaskan

2) Jenis kejadian yang tidak diinginkan:

Tim Persiapan melakukan dispute data kepemilikan tanah yang ingin dibebaskan

3) Peluang kejadian:

a. Tujuh kejadian dari 8 pengajuan pengadaan tanah untuk kegiatan eksplorasi dan ekploitasi.

b. Lima dari skala lima (5).

4) Dampak potensial bagi Pengadaan Tanah Untuk Kepentingan Umum: Terjadinya konflik dengan oknum yang masyarakat yang mengaku sebagai pemilik sah dari tanah tersebut mengkibatkan demostrasi dan pemblokiran jalan.

5) Kebijakan manajemen risiko:

Melakukan sosialisasi dengan cara penyampaian dan bahasa yang mudah dimengerti kepada masyarakat setempat, jika perlu menggunakan bahasa daerah setempat.

a. Tim Persiapan berkoordinasi dengan muspika selaku wakil pemerintah daerah terkecil seharusnya memiliki data kepemilikan tanah masyarakat setempat yang selalu terupdate, terupdate yang dimaksud adalah kepemilikan tanah warga benar secara hukum keabsahannya, dan apabila tanah tersebut telah diperjualbelikan muspika mengetahuinya dan memiliki copy berkas jual beli.

b. Melakukan sosialisasi dengan cara penyampaian dan bahasa yang mudah dimengerti kepada masyarakat setempat, jika perlu menggunakan bahasa daerah setempat.

6. Kebijakan manajemen risiko untuk tahapan Konsultasi Publik

I) Risiko Operasional:

Dispute data kepemilikan tanah yang ingin dibebaskan.

2) Jenis kejadian yang tidak diinginkan:

Tim Persiapan melakukan sosialisasi (Pemberitahuan Rencana Pembangunan) yang susah dimengerti maksud dan tujuannya oleh Pemilk lahan.

a. Tim Persiapan melakukan dispute data kepemilikan tanah yang ingin dibebaskan.

b. Pemilik lahan tidak menghadiri kegiatan Konsultasi Publik dikarenakan tidak sampainya undangan, dan pemilik lahan tidak mengerti maksud dan tujuan yang diutarakan oleh tim persiapan.

3) Peluang kejadian:

a. Tujuh kejadian dari 8 pengajuan pengadaan tanah untuk kegiatan eksplorasi dan ekploitasi.

b. Lima dari skala lima (5).

4) Dampak potensial bagi Pengadaan Tanah Untuk Kepentingan Umum: Pemilik lahan menolak akan pembangunan dan mempertahankan haknya (tidak ingin tanahnya dibebaskan)

5) Kebijakan manajemen risiko:

a. Tim Persiapan berkoordinasi dengan muspika selaku wakil pemerintah daerah terkecil seharusnya memiliki data kepemilikan tanah masyarakat setempat yang selalu terupdate, terupdate yang dimaksud adalah kepemilikan tanah warga benar secara hukum keabsahannya, dan apabila tanah tersebut telah diperjualbelikan muspika mengetahuinya dan memiliki copy berkas jual beli

b. Melakukan sosialisasi dengan cara penyampaian dan bahasa yang mudah dimengerti kepada masyarakat setempat, jika perlu menggunakan bahasa daerah setempat dan dimediasi oleh muspika setempat serta orang yang dituakan oleh warga setempat

7. Kebijakan manajemen risiko untuk tahapan Penetapan Lokasi

I. Risiko Operasional:

Dispute data kepemilikan tanah yang ingin dibebaskan 
2. Jenis kejadian yang tidak diinginkan:

Tim Persiapan melakukan dispute data kepemilikan tanah yang ingin dibebaskan

3. Peluang kejadian:

a. Lima kejadian dari 8 pengajuan pengadaan tanah untuk kegiatan eksplorasi dan ekploitasi.

b. Empat dari skala lima (5).

4. Dampak potensial bagi Pengadaan Tanah Untuk Kepentingan Umum: Inventarisasi kepemilikan lahan kembali mengakibatkan proses pengadaan lahan tidak sesuai dengan tata waktu yang sudah ditentukan dan pembengkakan anggaran operasional

5. Kebijakan manajemen risiko:

Tim Persiapan berkoordinasi dengan muspika selaku wakil pemerintah daerah terkecil seharusnya memiliki data kepemilikan tanah masyarakat setempat yang selalu terupdate, terupdate yang dimaksud adalah kepemilikan tanah warga benar secara hukum keabsahannya, dan apabila tanah tersebut telah diperjualbelikan muspika mengetahuinya dan memiliki copy berkas jual beli.

8. Kebijakan manajemen risiko untuk tahapan Penetapan Lokasi

I. Risiko Operasional:

Dispute data kepemilikan tanah yang ingin dibebaskan

2. Jenis kejadian yang tidak diinginkan:

Tim Persiapan melakukan dispute data kepemilikan tanah yang ingin dibebaskan

3. Peluang kejadian:

a. Lima kejadian dari 8 pengajuan pengadaan tanah untuk kegiatan eksplorasi dan ekploitasi.

b. Empat dari skala lima (5).

4. Dampak potensial bagi Pengadaan Tanah Untuk Kepentingan Umum: Terjadinya konflik dengan oknum yang masyarakat yang mengaku sebagai pemilik sah dari tanah tersebut mengkibatkan demostrasi dan pemblokiran jalan.

5. Kebijakan manajemen risiko:

Melakukan sosialisasi dengan cara penyampaian dan bahasa yang mudah dimengerti kepada masyarakat setempat, jika perlu menggunakan bahasa daerah setempat dan dimediasi oleh muspika setempat serta orang yang dituakan oleh warga setempat

9. Kebijakan manajemen risiko untuk tahapan Inventarisasi \& Identifikasi

I) Risiko Operasional:

Dispute data kepemilikan tanah yang ingin dibebaskan

2) Jenis kejadian yang tidak diinginkan: Tim Persiapan melakukan sosialisasi (Pemberitahuan Rencana Pembangunan) yang susah dimengerti maksud dan tujuannya oleh Pemilk lahan.

a. Tim Pelaksanaan melakukan dispute data kepemilikan tanah yang ingin dibebaskan

b. Tim Pelaksanaan melakukan kesalahan pengukuran tanah milik warga yang dibutuhkan untuk pengadaaan lahan untuk kepentingan umum

3) Peluang kejadian:

a. Dua kejadian dari 8 pengajuan pengadaan tanah untuk kegiatan eksplorasi dan ekploitasi.

b. Dua dari skala lima (5).

4) Dampak potensial bagi Pengadaan Tanah Untuk Kepentingan Umum: Inventarisasi \& Identifikasi ulang mengakibatkan proses pengadaan lahan tidak sesuai dengan tata waktu yang sudah ditentukan serta pembengkakan anggaran operasional.

5) Kebijakan manajemen risiko:

Melakukan sosialisasi dengan cara penyampaian dan bahasa yang mudah dimengerti kepada masyarakat setempat, jika perlu menggunakan bahasa daerah setempat.

a. Tim Persiapan berkoordinasi dengan muspika selaku wakil pemerintah daerah terkecil seharusnya memiliki data kepemilikan tanah masyarakat setempat yang selalu terupdate, terupdate yang dimaksud adalah kepemilikan tanah warga benar secara hukum keabsahannya, dan apabila tanah tersebut telah diperjualbelikan muspika mengetahuinya dan memiliki copy berkas jual beli

b. Tim pelaksanaan merupakan tim yang terdiri dari orang-orang yang berkompeten dibidangnya. Dan inventarisasi \& identifikasi dilakukan secara tidak terburu-buru (tidak satu waktu) 
I0. Kebijakan manajemen risiko untuk tahapan Inventarisasi \& identifikasi

I) Risiko Operasional:

Dispute data kepemilikan tanah yang ingin dibebaskan

2) Jenis kejadian yang tidak diinginkan:

Tim Persiapan melakukan sosialisasi (Pemberitahuan Rencana Pembangunan) yang susah dimengerti maksud dan tujuannya oleh Pemilk lahan.

a. Tim Pelaksanaan melakukan dispute data kepemilikan tanah yang ingin dibebaskan

b. Tim Pelaksanaan melakukan kesalahan pengukuran tanah milik warga yang dibutuhkan untuk pengadaaan lahan untuk kepentingan umum

3) Peluang kejadian:

a. Tiga kejadian dari 8 pengajuan pengadaan tanah untuk kegiatan eksplorasi dan ekploitasi.

b. Dua dari skala lima (5).

I. Dampak potensial bagi Pengadaan Tanah Untuk Kepentingan Umum: Terjadinya konflik dengan oknum yang masyarakat yang mengaku sebagai pemilik sah dari tanah tersebut mengkibatkan demostrasi dan pemblokiran jalan.

2. Kebijakan manajemen risiko:

Melakukan sosialisasi dengan cara penyampaian dan bahasa yang mudah dimengerti kepada masyarakat setempat, jika perlu menggunakan Bahasa daerah setempat.

a. Tim Pelaksanaan berkoordinasi dengan muspika selaku wakil pemerintah daerah terkecil seharusnya memiliki data kepemilikan tanah masyarakat setempat yang selalu terupdate, terupdate yang dimaksud adalah kepemilikan tanah warga benar secara hukum keabsahannya, dan apabila tanah tersebut telah diperjualbelikan muspika mengetahuinya dan memiliki copy berkas jual beli

b. Melakukan sosialisasi dengan cara penyampaian dan bahasa yang mudah dimengerti kepada masyarakat setempat, jika perlu menggunakan bahasa daerah setempat dan dimediasi oleh muspika setempat serta orang yang dituakan oleh warga setempat

\section{Kebijakan manajemen risiko untuk tahapan Penilaian Ganti Rugi}

I) Risiko Operasional:

Keberatan akan nilai ganti rugi/kompensasi yang sudah ditetapkan

2) Jenis kejadian yang tidak diinginkan:

Pemilik lahan tidak menghadiri kegiatan Konsultasi Publik dikarenakan tidak sampainya undangan, dan pemilik lahan tidak mengerti maksud dan tujuan yang diutarakan oleh tim persiapan

3) Peluang kejadian:

a. Tujuh kejadian dari 8 pengajuan pengadaan tanah untuk kegiatan eksplorasi dan ekploitasi.

b. Empat dari skala lima (5).

I. Dampak potensial bagi Pengadaan Tanah Untuk Kepentingan Umum: Dilakukan kembali Musyawarah Penetapan ganti Rugi ulang yang mengakibatkan proses pengadaan lahan tidak sesuai dengan tata waktu yang sudah di tentukan serta pembengkakan anggaran operasional

2. Kebijakan manajemen risiko:

Tim Persiapan berkoordinasi dengan muspika selaku wakil pemerintah daerah terkecil seharusnya memiliki data kepemilikan tanah masyarakat setempat yang selalu terupdate, terupdate yang dimaksud adalah kepemilikan tanah warga benar secara hukum keabsahannya, dan apabila tanah tersebut telah diperjualbelikan muspika mengetahuinya dan memiliki copy berkas jual beli

\section{I2. Kebijakan manajemen risiko untuk} tahapan Penilaian Ganti Rugi

I. Risiko Operasional:

Keberatan akan bentuk ganti rugi/kompensasi yang sudah ditetapkan

2. Jenis kejadian yang tidak diinginkan:

Munculnya gugatan dari warga pemilik lahan yang keberatan dengan nilai ganti rugi/kompensasi

\section{Peluang kejadian:}

a. Tujuh kejadian dari 8 pengajuan pengadaan tanah untuk kegiatan eksplorasi dan ekploitasi.

b. Empat dari skala lima (5).

4. Dampak potensial bagi Pengadaan Tanah Untuk Kepentingan Umum: Dilakukan kembali Musyawarah Penetapan ganti Rugi ulang yang mengakibatkan proses pengadaan lahan tidak 
sesuai dengan tata waktu yang sudah di tentukan pembengkakan anggaran operasional

5. Kebijakan manajemen risiko:

Tim Pelaksana berkoordinasi dengan muspika dan orang yang dituakan oleh warga setempat untuk memediasi kan dengan warga setempat bahwa, nilai ganti rugi yang ditawarkan merupakan penilaian oleh tim independent yang telah menilai objek tanah

13. Kebijakan manajemen risiko untuk tahapan Musyawarah Penetapan Ganti Rugi

I. Risiko Operasional:

Keberatan akan bentuk ganti rugi/kompensasi yang sudah ditetapkan

2. Jenis kejadian yang tidak diinginkan:

Tim Persiapan melakukan sosialisasi (Pemberitahuan Rencana Pembangunan) yang susah dimengerti maksud dan tujuannya oleh Pemilk lahan.

a. Tidak bertemunya kata sepakat antara warga dengan tim pelaksanaan

b. Pemilik lahan tidak menghadiri kegiatan Musyawarah Penetapan Ganti Rugi, dikarenakan tidak menerima undangan dan tidak mengertinya maksud dan tujuan dari Musyawarah Penetapan Ganti Rugi.

3. Peluang kejadian:

a. Tujuh kejadian dari 8 pengajuan pengadaan tanah untuk kegiatan eksplorasi dan ekploitasi.

b. Empat dari skala lima (5).

4. Dampak potensial bagi Pengadaan Tanah Untuk Kepentingan Umum:

Tuntutan/ demonstrasi hingga penutupan jalan.

5. Kebijakan manajemen risiko:

Melakukan sosialisasi dengan cara penyampaian dan bahasa yang mudah dimengerti kepada masyarakat setempat, jika perlu menggunakan bahasa daerah setempat.

a. Sosialisasi kan maksud dan tujuan dari Musyawarah Penetapan Ganti Rugi menggunakan bahasa yang mudah dimengerti kepada masyarakan setempat, jika perlu menggunakan bahasa daerah setempat dan dimediasi oleh muspika serta orang yang dituakan oleh warga setempat.

b. Tim Pelaksana berkoordinasi dengan muspika dan orang yang dituakan oleh warga setempat untuk memediasi kan dengan warga setempat bahwa, bentuk ganti rugi yang ditawarkan merupakan penilaian oleh tim independent yang telah menilai objek tanah

I4. Kebijakan manajemen risiko untuk tahapan Musyawarah Penetapan Ganti Rugi

I) Risiko Operasional:

Keberatan akan bentuk ganti rugi/kompensasi yang sudah ditetapkan

2) Jenis kejadian yang tidak diinginkan:

Tim Persiapan melakukan sosialisasi (Pemberitahuan Rencana Pembangunan) yang susah dimengerti maksud dan tujuannya oleh pemilk lahan.

a. Munculnya gugatan dari warga pemilik lahan yang keberatan dengan bentuk ganti rugi/kompensasi mengakibatkan tuntutan/ demonstrasi hingga penutupan jalan.

b. Pemilik lahan tidak menghadiri kegiatan Musyawarah Penetapan Ganti Rugi, dikarenakan tidak menerima undangan dan tidak mengertinya maksud dan tujuan dari Musyawarah Penetapan Ganti Rugi

\section{3) Peluang kejadian:}

a. Tujuh kejadian dari 8 pengajuan pengadaan tanah untuk kegiatan eksplorasi dan ekploitasi.

b. Empat dari skala lima (5).

4) Dampak potensial bagi Pengadaan Tanah Untuk Kepentingan Umum: Inventarisasi \& Identifikasi ulang mengakibatkan mundurnya proses kegiatan mengakibatkan proses pengadaan lahan tidak sesuai dengan tata waktu yang sudah ditentukan serta pembengkakan anggaran operasional

5) Kebijakan manajemen risiko:

Melakukan sosialisasi dengan cara penyampaian dan bahasa yang mudah dimengerti kepada masyarakat setempat, jika perlu menggunakan bahasa daerah setempat.

a. Sosialisasi kan maksud dan tujuan dari Musyawarah Penetapan Ganti Rugi menggunakan bahasa yang mudah dimengerti kepada masyarakan setempat, jika perlu menggunakan bahasa daerah setempat dan dimediasi oleh muspika serta orang yang dituakan oleh warga setempat. 
b. Tim Pelaksana berkoordinasi dengan muspika dan orang yang dituakan oleh warga setempat untuk memediasi kan dengan warga setempat bahwa, bentuk ganti rugi yang ditawarkan merupakan penilaian oleh tim independent yang telah menilai objek tanah

I5. Kebijakan manajemen risiko untuk tahapan Pemberian Ganti Rugi

I. Risiko Operasional:

Dispute data kepemilikan tanah yang ingin dibebaskan

2. Jenis kejadian yang tidak diinginkan:

Tim Pelaksanaan melakukan dispute data kepemilikan tanah yang ingin dibebaskan saat proses pembayaran berlangsung

3. Peluang kejadian:

a. Tujuh kejadian dari 8 pengajuan pengadaan tanah untuk kegiatan eksplorasi dan ekploitasi.

b. Empat dari skala lima (5).

4. Dampak potensial bagi Pengadaan Tanah Untuk Kepentingan Umum: Inventarisasi \& Identifikasi ulang mengakibatkan mundurnya proses kegiatan mengakibatkan proses pengadaan lahan tidak sesuai dengan tata waktu yang sudah ditentukan serta pembengkakan anggaran operasional

5. Kebijakan manajemen risiko:

a. Proses Inventarisasi \& Identifikasi dilakukan dengan semaksimal mungkin untuk mengidentifikasi kepemilikan lahan.

b. Tim Persiapan berkoordinasi dengan muspika selaku wakil pemerintah daerah terkecil seharusnya memiliki data kepemilikan tanah masyarakat setempat yang selalu terupdate, terupdate yang dimaksud adalah kepemilikan tanah warga benar secara hukum keabsahannya, dan apabila tanah tersebut telah diperjualbelikan muspika mengetahuinya dan memiliki copy berkas jual beli.

16. Kebijakan manajemen risiko untuk tahapan Pemberian Ganti Rugi

I. Risiko Operasional:

Dispute data kepemilikan tanah yang ingin dibebaskan

2. Jenis kejadian yang tidak diinginkan:

Tim Pelaksanaan melakukan dispute data kepemilikan tanah yang ingin dibebaskan saat proses pembayaran berlangsung

3. Peluang kejadian:

a. Tujuh kejadian dari 8 pengajuan pengadaan tanah untuk kegiatan eksplorasi dan ekploitasi.

b. Empat dari skala lima (5).

4. Dampak potensial bagi Pengadaan Tanah Untuk Kepentingan Umum:

Tuntutan/ demonstrasi hingga penutupan jalan.

5. Kebijakan manajemen risiko:

Sosialisasi menggunakan bahasa yang mudah dimengerti kepada masyarakan setempat, jika perlu menggunakan bahasa daerah setempat dan dimediasi oleh muspika serta orang yang dituakan oleh warga setempat.

17. Kebijakan manajemen risiko untuk tahapan Penghapusan Hak

I. Risiko Operasional:

Tidak adanya pemilik lahan saat proses penghapusan hak

2. Jenis kejadian yang tidak diinginkan:

Undangan kegiatan Pelepasan dan penghapusan hak atas tanah dari Tim Pelaksanaan tidak sampai kepada pemilik lahan,

3. Peluang kejadian:

a. Tujuh kejadian dari 8 pengajuan pengadaan tanah untuk kegiatan eksplorasi dan ekploitasi.

b. Empat dari skala lima (5).

4. Dampak potensial bagi Pengadaan Tanah Untuk Kepentingan Umum: Dilakukan reschedule kegiatan pelepasan dan penghapusan hak atas tanah maka akan terjadi pembengkakan anggaran operasional

5. Kebijakan manajemen risiko:

Tim Pelaksana berkoordinasi dengan muspika dan orang yang dituakan oleh warga setempat untuk memastikan para undangan untuk hadir dalam kegiatan tersebut

18. Kebijakan manajemen risiko untuk tahapan Serah Terima Dokumen

\section{Risiko Operasional:}

Keterlambatan proses serah terima dokumen 
pengadaan tanah dari tim pelaksanaan kepada Instansi yang membutuhkan

2. Jenis kejadian yang tidak diinginkan:

Tim Pelaksanaan melakukan keterlambatan serah terima dokumen kepada instansi yang membutuhkan tanah

3. Peluang kejadian:

a. Tujuh kejadian dari 8 pengajuan pengadaan tanah untuk kegiatan eksplorasi dan ekploitasi.

b. Empat dari skala lima (5).

4. Dampak potensial bagi Pengadaan Tanah Untuk Kepentingan Umum: Mundurnya waktu pengerjaan proyek, dikarenakan instansi yang membutuhkan lahan belum menerima dokumen pelepasan dan penghapusan hak dari tim pelaksanaan

5. Kebijakan manajemen risiko:

Berkoordinasi dengan tim pelaksanaan PIC (BPN) untuk menanyakan update proses administrasi setiap harinya. Dan berkoordinasi dengan tim pengatur jadwal pejabat Pemeritah Daerah untuk selalu mengingatkan penyelesaian proses adminstrasi harus segera diselesaikan oleh pejabat Pemerintah Daerah.

\section{KESIMPULAN \& SARAN}

\section{I Kesimpulan}

Berdasarkan uraian yang telah dijelaskan dalam bab terdahulu maka, peneliti dapat menyimpulkan halhal sebagai berikut :

I Identifikasi risiko kegagalan operasional pengadaan tanah untuk kegiatan eksplorasi dan ekploitasi Studi Kasus di PT.Pertamina EP - Paku Gajah Development Project dapat dipetakan melalui tahapan aktivitas operasional seperti dibawah ini :

a. Tahapan kegiatan operasional Perencanaan

b. Tahapan kegiatan operasional Persiapan

c. Tahapan kegiatan operasional Pelaksanaan

d. Tahapan kegiatan operasional Penyerahan Hasil

2 Hasil identifikasi risiko operasional berdasarkan analisa peluang dan dampak dari masing-masing tahapan yang menyebabkan menyebabkan terhambatnya proses tahapan tersebut diindikasi- kan memiliki nilai Risk Assessment Matrix High. Dengan rincian hasil sebagai berikut :

a. Hasil identifikasi risiko operasional terkait dengan tahapan Perencanaan yang menjadi perhatian khusus adalah :

Pengajuan Dokumen,

b. Hasil identifikasi risiko operasional dan terkait dengan tahapan Persiapan yang menjadi perhatian khusus adalah :

$\square$ Pendataan Awal,

$\square$ Konsultasi Publik,

3. Mitigasi pada setiap tahapan kegiatan pengadaan tanah untuk kegiatan eksplorasi dan ekploitasi PT.Pertamina EP-Paku Gajah Development Project adalah :

\section{Perencanaan}

Mitigasi yang dapat dilakukan pada tahapan Pengajuan Dokumen jenis risiko operasional adalah:

- Survey pendahuluan ke lokasi yang dibutuhkan untuk mengumpulkan seluruh data yang dibutuhkan

\section{Persiapan}

- Mitigasi yang dapat dilakukan pada tahapan Pendataan awal yang memiliki jenis risiko operasional adalah:

Tim Persiapan perlu berkoordinasi dengan muspika selaku wakil pemerintah daerah terkecil yang memiliki data kepemilikan tanah masyarakat setempat yang selalu terupdate.

- Mitigasi yang dapat dilakukan pada tahapan Pendataan awal yang memiliki jenis risiko sosial adalah:

Melakukan sosialisasi dengan cara penyampaian dan bahasa yang mudah dimengerti kepada masyarakat setempat.

- Mitigasi yang dapat dilakukan pada tahapan Konsultasi Publik yang memiliki jenis risiko operasional adalah :

Tim Persiapan perlu berkoordinasi dengan muspika selaku wakil pemerintah daerah terkecil yang memiliki data kepemilikan tanah masyarakat setempat yang selalu terupdate.

Mitigasi yang dapat dilakukan pada tahapan Konsultasi Publik yang memiliki jenis risiko sosial adalah: 
- Tim Persiapan perlu berkoordinasi dengan muspika selaku wakil pemerintah daerah terkecil yang memiliki data kepemilikan tanah masyarakat setempat yang selalu terupdate.

- Melakukan sosialisasi dengan cara penyampaian dan bahasa yang mudah dimengerti kepada masyarakat setempat.

\subsection{Saran}

Berdasarkan kesimpulan yang telah dikemukakan diatas maka dapat dibuat saran sebagai berikut:

PT.Pertamina EP- Paku Gajah Development Project disarankan untuk melakukan review kembali terkait proses pengadaan tahan untuk kegiatan eksplorasi dan ekploitasi khususnya pada tahapan pengadaan tanah kegiatan eksplorasi dan ekploitasi yang memiliki nilai risiko High. Review yang dimaksud adalah perlakuan atau penerapan dari tahapan-tahapan pengadaan tahan untuk kegiatan eksplorasi dan ekploitasi yang memiliki nilai risiko High harus dihentikan atau mengganti cara atau penerapan yang baru untuk meminimalisir tahapan tersebut.

Dan tahapan yang memiliki nilai risiko Substansial, Medium, dan Low, mitigas yang dilakukan adalah melakukan followup kepada cara atau penerapan pada kegiatan tersebut.

\section{DAFTAR PUSTAKA}

\section{A.Buku}

Republik Indonesia. (n.d.). Keputusan Presiden Nomor 55 tahun 1993 Tentang

Pengadaan Tanah Bagi Pelaksanaan Pembangunan Untuk Kepentingan Umum.

Australian Standard/New Zealand Standard 4360:1999. (1999). Sydney: Risk Management Guidelines.

Australian Standard/New Zealand Standard 4360:2004. (2004). Sydney: Risk Management Guidelines.

Fraser, J., \& J. Simkins, B. (2010). Enterprise Risk Management. Canada : John Wiley\& Sons .

Mario ,F , T. (1998). Elementary Statistics (7th ed.). New York: Addison-Wesley.

ramli, s. (20 I0). Pedoman Praktis manajemen Risiko Dalam Prespektif K3. Jakarta : PT.Dian Rakyat.

Ridley, J. (2008). Ikhtisar Kesehatan dan Keselamatan Kerja (Ketiga ed.). Jakarta: Erlangga.

Suardi, R. (2005). Sistem Manajemen Kesehatan kerja. Jakarta : PT.Toko Gunung Agung .

Sunaryo,T. (2007). Manajemen Risiko Finansial (Vol. empat ). Jakarta : Salemba.

Syah, M. I. (20I5). pembebasan tanah untuk pembangunan kepentingan umum upaya hukum masyarakat yang terkena pembebasan dan pencabutan hak (Vol. III).

Jakarta : Permata Aksara.

B.Peraturan Perundang-Undangan

Republik Indonesia . (n.d.). Undang-Undang No.22 Tahun 200I Tentang Minyak dan Gas Bumi.

Republik Indonesia.(n.d.). Instruksi Presiden Nomor 2 Tahun 20 I 2 Tentang Peningkatan Produksi Minyak dan Gas Bumi Nasional.

Republik Indonesia. (n.d.). Instruksi Presiden Republik Indonesia No.2 tahun 2012
Tentang Peningkatan Produksi Minyak Bumi Nasional.

Republik Indonesia. (n.d.). Peraturan Menteri Tenaga Kerja No.05/ MEN/I999 Tentang Sistem Manajemen Keselamatan Kesehatan Kerja (SMK3).

Republik Indonesia. (n.d.). Peraturan Presiden Republik Indonesia No.l48 Tahun 2015 Tentang Perubahan Keempat atas Peraturan Presiden Nomor 7I Tahun 2012 Tentang Penyelenggaraan Pengadaan Tanah Bagi Pembangunan Untuk Kepentingan Umum.

Republik Indonesia. (n.d.). Peraturan Presiden Republik Indonesia No.30Tahun 20I5 Tentang Perubahan Ketiga atas Peraturan Presiden Nomor 7I Tahun 2012 Tentang Penyelenggaraan Pengadaan Tanah Bagi Pembangunan Untuk

Kepentingan Umum

Republik Indonesia. (n.d.). Peraturan Presiden Republik Indonesia No.40Tahun 2014Tentang Perubahan atas Peraturan Presiden Nomor 7 I Tahun 2012 Tentang Penyelenggaraan Pengadaan Tanah Bagi Pembangunan Untuk Kepentingan Umum.

Republik Indonesia. (n.d.). Peraturan Presiden Republik Indonesia No.7I Tahun 2012 Tentang Penyelenggaraan Pengadaan Tanah Bagi Pembangunan Untuk

Kepentingan Umum

Republik Indonesia. (n.d.). Peraturan Presiden Republik Indonesia No.99Tahun 2014 Tentang Perubahan Kedua atas Peraturan Presiden Nomor 7I Tahun 2012 Tentang Penyelenggaraan Pengadaan Tanah Bagi Pembangunan Untuk

Kepentingan Umum.

Republik Indonesia. (n.d.). Undang-Undang Dasar Negara Republik Indonesia Tahun 1945 Pasal 33 Ayat(3).

Republik Indonesia. (n.d.). Undang-Undang No.2 tahun 2012 Tentang Pengadaan

Tanah Bagi Pembangunan Untuk Kepentingan Umum. 